\title{
A description and evaluation of an air quality model nested within global and regional composition-climate models using MetUM
}

\author{
Lucy S. Neal ${ }^{1}$, Mohit Dalvi ${ }^{2}$, Gerd Folberth ${ }^{2}$, Rachel N. McInnes ${ }^{2,3}$, Paul Agnew $^{1}$, Fiona M. O'Connor ${ }^{2}$, \\ Nicholas H. Savage ${ }^{1}$, and Marie Tilbee ${ }^{1}$ \\ ${ }^{1}$ Met Office, FitzRoy Road, Exeter, EX1 3PB, UK \\ ${ }^{2}$ Met Office Hadley Centre, FitzRoy Road, Exeter, EX1 3PB, UK \\ ${ }^{3}$ European Centre for Environment and Human Health, University of Exeter Medical School, Knowledge Spa, \\ Royal Cornwall Hospital, Truro, TR1 3HD, UK
}

Correspondence to: Lucy S. Neal (lucy.neal@metoffice.gov.uk)

Received: 15 March 2017 - Discussion started: 27 March 2017

Revised: 18 August 2017 - Accepted: 15 September 2017 - Published: 1 November 2017

\begin{abstract}
There is a clear need for the development of modelling frameworks for both climate change and air quality to help inform policies for addressing these issues simultaneously. This paper presents an initial attempt to develop a single modelling framework, by introducing a greater degree of consistency in the meteorological modelling framework by using a two-step, one-way nested configuration of models, from a global composition-climate model (GCCM) (140 km resolution) to a regional composition-climate model covering Europe (RCCM) $(50 \mathrm{~km}$ resolution) and finally to a high $(12 \mathrm{~km})$ resolution model over the UK (AQUM). The latter model is used to produce routine air quality forecasts for the UK. All three models are based on the Met Office's Unified Model (MetUM). In order to better understand the impact of resolution on the downscaling of projections of future climate and air quality, we have used this nest of models to simulate a 5-year period using present-day emissions and under present-day climate conditions. We also consider the impact of running the higher-resolution model with higher spatial resolution emissions, rather than simply regridding emissions from the RCCM. We present an evaluation of the models compared to in situ air quality observations over the UK, plus a comparison against an independent $1 \mathrm{~km}$ resolution gridded dataset, derived from a combination of modelling and observations, effectively producing an analysis of annual mean surface pollutant concentrations. We show that using a high-resolution model over the UK has some benefits in improving air quality modelling, but that the use of higher spatial resolution emissions is important to capture local vari-
\end{abstract}

ations in concentrations, particularly for primary pollutants such as nitrogen dioxide and sulfur dioxide. For secondary pollutants such as ozone and the secondary component of $\mathrm{PM}_{10}$, the benefits of a higher-resolution nested model are more limited and reasons for this are discussed. This study highlights the point that the resolution of models is not the only factor in determining model performance - consistency between nested models is also important.

\section{Introduction}

Models for studying historical climate change and for projecting future climate have increased in complexity and sophistication in recent years and the importance of including atmospheric composition as a component of such models is now well established (e.g. Eyring et al., 2013). Gas-phase pollutants, such as tropospheric ozone $\left(\mathrm{O}_{3}\right)$, exert a positive radiative forcing on climate (Stevenson et al., 2013; Myhre et al., 2013), while the radiative forcings associated with aerosol-radiation and aerosol-cloud interactions are partly masking the strong positive forcing associated with longlived greenhouse gases (Myhre et al., 2013). A changing climate, in turn, has an impact on both natural emissions (e.g. Sanderson et al., 2003; Forkel and Knoche, 2006) and chemistry and aerosol processes themselves (e.g. Jacob and Winner, 2009; Fiore et al., 2012; Allen et al., 2016), influencing atmospheric composition. Atmospheric composition and near-surface air quality are intricately linked and poor air 
quality has impacts on human health (e.g. WHO, 2013a). In addition, surface $\mathrm{O}_{3}$ can adversely impact crop growth (Sitch et al., 2007), while aerosols can potentially promote global plant productivity by increasing the diffuse fraction of photosynthetically active radiation (Mercado et al., 2009).

Given the interactions between atmospheric composition, air quality, and climate, it is essential that the development of climate change mitigation policies and air quality abatement strategies are developed jointly and consider the full spectrum of co-benefits and trade-offs (e.g. von Schneidemesser and Monks, 2013). As a result, there is a strong need for models that can simulate both climate and air quality. Likewise, it is also necessary to develop modelling frameworks which can dynamically downscale global climate and air quality projections to the regional scale, on which population centres and crop locations vary significantly. Downscaling allows a greater level of detail to be made explicit and analysed. Air pollutant concentrations exhibit a high degree of spatial inhomogeneity compared to meteorological fields such as temperature and wind, and more highly resolved regional modelling can improve the representation and evolution due to more highly resolved emissions and the dependence of reaction rates on concentrations of reactive species. A further imperative for higher-resolution modelling concerns the sensitivity of composition projections to the difference in meteorology. For example, Kunkel et al. (2008) discuss the sensitivity of $\mathrm{O}_{3}$ under regional climate change to cumulus cloud parametrizations. In their review article, Jacob and Winner (2009) cite a number of other examples where significantly differing model predictions are attributed to differences in air pollution meteorology between global and higher-resolution regional models.

Various modelling configurations have been employed in studies of regional air quality in the context of present-day climate and under future climate change scenarios. A common approach has been to use a global-regional climate model nest to provide meteorology and then use the stored fields to drive an offline chemistry transport model (CTM) (e.g. Lauwaet et al., 2013; Likhvar et al., 2015). This approach was used, for example, to investigate the impacts of emission changes on $\mathrm{UK} \mathrm{O}_{3}$ and European air quality by Heal et al. (2013) and Colette et al. (2011), respectively. Another example is Chemel et al. (2014), which nests the WRF-CMAQ (Weather Research and Forecasting - Community Multi-scale Air Quality) air quality model (Wong et al., 2012) over the UK domain inside a European regional model but takes initial and lateral boundary conditions (LBCs) for composition and climate from two different global models. Some examples of future climate and air quality simulations are those carried out by Trail et al. (2014), Meleux et al. (2007), and Langner et al. (2012). Recognizing the advantages of more closely coupled meteorology and composition, online models have increasingly been developed. Initially this was mainly in the context of global general circulation models (GCMs) for climate modelling, where long timescale simulations potentially render even small feedback mechanisms between composition and meteorology important. Results from some of these models have been used in the latest Intergovernmental Panel on Climate Change (IPCC) Assessment reports (Boucher et al., 2013; Myhre et al., 2013; Lamarque et al., 2013). Online regional chemistry models are a more recent development, with applications to air quality forecasting (e.g. Savage et al., 2013; Baklanov et al., 2014) and impacts from a changing climate (e.g. Shalaby et al., 2012; Colette et al., 2011; Forkel and Knoche, 2006). Hong et al. (2017), for example, nest the WRF-CMAQ online regional model inside the atmospheric component of the Community Earth System Model (CESM; Hurrell et al., 2013) and referred to the configuration as CESM-NCSU (CESM - North Carolina State University; He et al., 2015). Single online chemistry models that can be used at all scales, from global through regional and even to urban-scale resolutions, represent the most advanced modelling configuration. The first model with this capability was GATORGCMM (gas, aerosol, transport, radiation, general circulation and mesoscale model; Jacobson, 2001), which linked existing global and regional versions of the GATOR model such that the gas, aerosol, and radiative parts of the two scales were the same, although the meteorological and transport parts differed. This capability has also since been implemented more recently in GU-WRF/Chem (Zhang et al., 2012), which started from a mesoscale model WRF-Chem (e.g. Grell et al., 2005) re-configured for the global scale. These models are capable of running regional models nested within a consistent global chemistry model.

In this paper we describe and evaluate a new modelling framework which uses a more consistent set of models to go from the global scale down to the UK national scale. We employ the Met Office's Unified Model, MetUM (Brown et al., 2012), to downscale from a global composition-climate model (GCCM) configuration to the UK national scale, via a regional composition-climate model (RCCM) configuration. At each scale, model configurations of MetUM appropriate to the resolution are employed, but the use of a single framework results in a higher degree of consistency across the scales. The global climate model used is based on the Global Atmosphere 3.0 (GA3.0) configuration of HadGEM3 (Walters et al., 2011) and the RCCM is a limited area version, described by Moufouma-Okia and Jones (2015). The inner nest is the AQUM regional air quality forecast model. This operates at a resolution of $12 \mathrm{~km}$ and is used operationally to provide the UK national air quality forecast. The forecasts generated by AQUM are evaluated against hourly pollutant measurements on a daily basis (Savage et al., 2013). Whilst we have sought to maximize consistency between the models, there do remain some differences and these are noted and described in subsequent sections. The purpose of the present paper is to describe the new modelling framework and to evaluate simulations of present-day air quality by comparing against UK observations. The paper is structured as follows. 
Section 2 describes the modelling framework employed in this study. Section 3 describes the experimental set-up of the present-day simulations. Section 4 presents results on the performance of the nested configurations and a discussion with concluding remarks can be found in Sect. 5. This modelling framework has also been used to downscale global climate and air quality projections for the 2050s onto the UK national scale and is discussed in Folberth et al. (2017a).

\section{Modelling system description}

In this section, we provide a brief overview of each of the scientific configurations of the MetUM employed in this study (this is presented in tabular form to allow comparison of the model configurations in Table A1 in Appendix A). We give a summary description of the model dynamics and model physics, and details of the two-step, one-way nesting approach developed. A discussion of the chemistry and aerosol schemes is also included.

\subsection{Global Composition-Climate Model (GCCM)}

The GCCM is based on the Global Atmosphere 3.0/Global Land 3.0 (GA3.0/GL3.0) configuration of the Hadley Centre Global Environmental Model version 3 (HadGEM3, Walters et al., 2011), of the Met Office's Unified Model (MetUM, Brown et al., 2012). Soil-vegetation-atmosphere interactions are calculated using the Joint UK Land Environment Simulator (JULES, Best et al., 2011) and a full description of the GCCM can be found in Walters et al. (2011). The model has a horizontal resolution of $1.875^{\circ} \times 1.25^{\circ}$, which translates to approximately $140 \mathrm{~km} \times 140 \mathrm{~km}$ at the mid-latitudes. The model has 63 levels in the vertical, spanning up to $41 \mathrm{~km}$ with the first 50 levels below $18 \mathrm{~km}$. The model's dynamical time step is $20 \mathrm{~min}$.

The GA3.0 configuration of HadGEM3 (Walters et al., 2011) incorporates an interactive aerosol scheme, CLASSIC (Coupled Large-scale Aerosol Simulator for Studies in Climate; Jones et al., 2001; Bellouin et al., 2011). CLASSIC is a mass-based aerosol scheme in which all the aerosol components are treated as external mixtures. The scheme simulates ammonium sulfate, mineral dust, soot, fossil-fuel organic carbon (FFOC), biomass burning (BB), and ammonium nitrate in a prognostic (evolving) manner, and biogenic secondary organic aerosols are prescribed from a climatology. Sea salt is treated as a diagnosed quantity over sea points in the model; a limitation of this is that it does not contribute to particulate matter predictions over land points. The aerosols can influence the atmospheric radiative and cloud properties through aerosol-radiation and aerosol-cloud interactions, but for this study, these interactions have been switched off. The reasons for this were 2-fold: (1) the primary focus of this study was on the simulation of air quality, and not on the impact of air quality on model dynamics, and
(2) for statistical significance, much longer simulations are required when radiative and microphysical feedbacks are active (typically 20-30 model years as opposed to 5-7 years without these feedbacks).

The gas-phase chemistry in the GCCM is simulated by a tropospheric configuration of the United Kingdom Chemistry and Aerosol (UKCA) model (Morgenstern et al., 2009; O'Connor et al., 2014). However, for this study, the two tropospheric chemistry schemes described in O'Connor et al. (2014) were replaced by an extended tropospheric chemistry scheme, called UKCA-ExtTC. This version of UKCA applies a more detailed gas-phase chemistry scheme that has a significantly larger number of chemical species -89 chemical species in comparison to the 41 and 55 in the StdTrop and TropIsop chemistry schemes in O'Connor et al. (2014), respectively - and chemical reactions - 203 in UKCA-ExtTC in comparison to the 121 and 164 described in O'Connor et al. (2014). The UKCA-ExtTC chemical mechanism has been designed to represent the key chemical species and reactions in the troposphere in as much detail as is necessary to simulate atmospheric composition and air quality, while retaining the capability to conduct decade-long climate simulations. As a result, it is more suitable for air quality studies and has been applied successfully in previous studies (e.g. Ashworth et al., 2012; Pacifico et al., 2015). Of the 89 chemical species that UKCA-ExtTC considers, 63 are transported as "tracers". For the remaining 26 species, transport is negligible in comparison to chemical transformation during one model time step, and hence they are treated as "steady-state" species. UKCA-ExtTC uses the same backward Euler solver, a chemical time step (5 min), wet and dry deposition, largescale and convective transport, and boundary layer treatment of tracers as described in O'Connor et al. (2014). A separate, detailed description of this extended version of UKCA is in preparation (Folberth et al., 2017b).

Although UKCA has two options in relation to photolysis (O'Connor et al., 2014), the photolysis reactions in this configuration are handled using offline rates, calculated in the Cambridge 2-D model (Law and Pyle, 1993) using the two-stream approach of Hough (1988). We used this option in the GCCM and RCCM configurations mainly for two reasons. First, the extended tropospheric chemistry version of UKCA, UKCA-ExtTC, has been developed and extensively evaluated only with the 2-D photolysis model, and there was no time within the scope of this work for development and evaluation of UKCA-ExtTC coupled to the Fast-J online photolysis model. Second, there is a non-negligible, albeit not prohibitively large, extra cost attached to using the Fast-J online photolysis scheme over the 2-D photolysis scheme. With the offline photolysis scheme, the photolysis rates are read in by UKCA-ExtTC on the first time step of the model integration and interpolated in time and space at each model grid box. The impact of cloud cover, surface albedo, and aerosols is included in the form of a climatological cloud cover, prescribed albedo, and aerosol loading, respectively. 
A two-way coupling between the UKCA-ExtTC chemistry scheme and the CLASSIC aerosol scheme is applied through the provision of simulated oxidant species (ozone $\left(\mathrm{O}_{3}\right)$, the hydroxyl $(\mathrm{OH})$ and hydroperoxyl $\left(\mathrm{HO}_{2}\right)$ radicals, and hydrogen peroxide $\left(\mathrm{H}_{2} \mathrm{O}_{2}\right)$ ) and the provision of nitric acid $\left(\mathrm{HNO}_{3}\right)$ as a nitrate aerosol precursor. Oxidation of sulfur dioxide $\left(\mathrm{SO}_{2}\right)$ and dimethyl sulfide (DMS) occurs in both the gas phase and the aqueous phase to form sulfate aerosol and the $\mathrm{HNO}_{3}$ generates ammonium nitrate aerosol with any remaining ammonium ions after reaction with sulfate. The coupling is two-way because gas-phase concentrations of both $\mathrm{H}_{2} \mathrm{O}_{2}$ and $\mathrm{HNO}_{3}$ are depleted, following sulfate and nitrate aerosol formation.

Although UKCA does include an aerosol microphysics scheme, GLOMAP-mode (Mann et al., 2010), the simpler mass-based CLASSIC aerosol scheme (Jones et al., 2001; Bellouin et al., 2011) was used across the three MetUM configurations for the following reasons: (1) the UKCAExtTC chemistry scheme has historically only been coupled to the CLASSIC scheme and there was no time within the scope of the current study to couple it to GLOMAP-mode, (2) the operational air quality forecast model, AQUM, also uses CLASSIC as its aerosol scheme, and one of the aims of this work was to maximize the consistency in the treatment of both meteorology and composition across the three model domains, and (3) the computational cost of running both UKCA-ExtTC and GLOMAP-mode would have been prohibitively expensive.

\subsection{Regional Composition-Climate Model (RCCM)}

The RCCM, referred to as the HadGEM3-A "regional" (HadGEM3-RA) configuration, is described in detail in Moufouma-Okia and Jones (2015), and is also based on the GA3.0/GL3.0 configuration of HadGEM3 (Walters et al., 2011). The RCCM has a horizontal resolution of $0.44^{\circ} \times 0.44^{\circ}$ (roughly $50 \mathrm{~km} \times 50 \mathrm{~km}$ ) with a domain covering most of Europe and northern Africa (Fig. 1) and the same 63 vertical levels as the GCCM. The RCCM closely follows the GCCM configuration (Sect. 2.1), with the same dynamical solver, radiation, precipitation, and cloud (PC2) schemes. The same principal components are included: the UKCAExtTC chemistry model, the CLASSIC aerosol model, and the JULES land-surface model. The model dynamical time step was reduced to $12 \mathrm{~min}$ ( $20 \mathrm{~min}$ in GCCM) to account for the increase in resolution and shorter turnaround of dynamical processes and interactions. The chemical time step is $5 \mathrm{~min}$. Boundary conditions, used to drive the RCCM from the GCCM, will be discussed in Sect. 3 .

\subsection{AQUM}

The final, high-resolution nest employed is the AQUM (Air Quality in the Unified Model) air quality forecast model. AQUM, like both the GCCM and the RCCM, is based on the

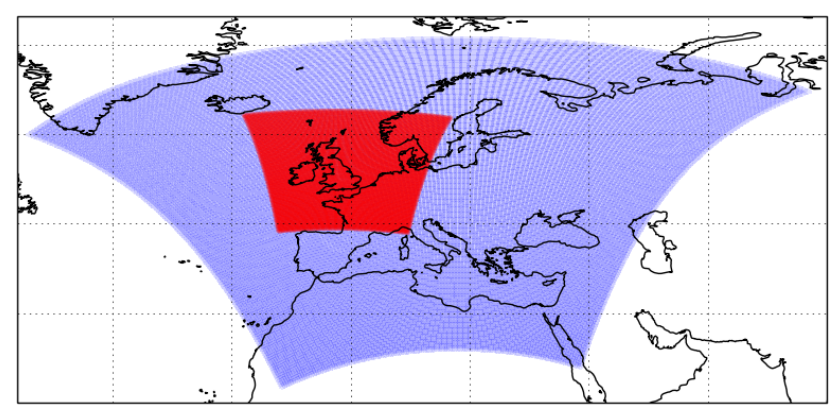

Figure 1. Nested modelling domains. The rectangular boundary of the figure is an extract of the GCCM (resolution $140 \mathrm{~km}$ ) containing the RCCM domain (resolution $50 \mathrm{~km}$ ) plotted in blue and the AQUM domain (resolution $12 \mathrm{~km}$ ) in red.

MetUM. AQUM has a horizontal resolution of $0.11^{\circ} \times 0.11^{\circ}$ (approximately $12 \mathrm{~km} \times 12 \mathrm{~km}$ ) on a "rotated pole" grid, covering the UK and nearby western Europe (see Fig. 1), with 38 vertical levels up to $39 \mathrm{~km}$. The LBCs, provided by the RCCM, are on 63 levels but interpolated onto the 38 levels of AQUM. The dynamical and chemistry time steps are both $5 \mathrm{~min}$.

The set-up of this model is described in detail in Savage et al. (2013) and uses the same parametrization schemes as the global and regional CCMs described above, apart from large-scale cloud, where AQUM uses the diagnostic cloud scheme as described by Smith (1990). As with the GCCM and RCCM, AQUM uses the CLASSIC aerosol scheme (Jones et al., 2001; Bellouin et al., 2011) and the UKCA model for its gas-phase chemistry. This helps to improve consistency between many aspects of the models. For example, large-scale and convective transport, boundary layer mixing, and wet and dry deposition are similar between all the nests. However, a different chemistry mechanism, the Regional Air Quality (RAQ) scheme, is used and the photolysis scheme also differs. Photolysis rates in AQUM are calculated with the Fast-J online photolysis scheme (Wild et al., 2000; O'Connor et al., 2014), which is coupled to the modelled liquid water and ice content, and sulfate aerosols at every time step.

The RAQ chemistry scheme pre-dates the ExtTC scheme and has been used in AQUM throughout its development and use as a forecast model. The experience developed with AQUM and the understanding of model performance established relies on the continuing use of this scheme and therefore we chose to retain this scheme for the final nest. The scheme has 40 transported species, 18 non-advected species, 116 gas-phase reactions, and 23 photolysis reactions; 16 of the transported species are emitted: nitrogen oxide (NO), methane $\left(\mathrm{CH}_{4}\right)$, carbon monoxide $(\mathrm{CO})$, formaldehyde $(\mathrm{HCHO})$, ethane $\left(\mathrm{C}_{2} \mathrm{H}_{6}\right)$, acetaldehyde $\left(\mathrm{CH}_{3} \mathrm{CHO}\right)$, propane $\left(\mathrm{C}_{3} \mathrm{H}_{8}\right)$, acetone $\left(\mathrm{CH}_{3} \mathrm{COCH}_{3}\right)$, isoprene $\left(\mathrm{C}_{5} \mathrm{H}_{8}\right)$, methanol $\left(\mathrm{CH}_{3} \mathrm{OH}\right)$, hydrogen $\left(\mathrm{H}_{2}\right)$, ethene $\left(\mathrm{C}_{2} \mathrm{H}_{4}\right)$, propene 
$\left(\mathrm{C}_{3} \mathrm{H}_{6}\right)$, butane $\left(\mathrm{C}_{4} \mathrm{H}_{10}\right)$, toluene, and o-xylene. As was the case in the GCCM and the RCCM, there is two-way coupling of oxidants between CLASSIC and the RAQ chemistry scheme. Further details of the RAQ scheme can be found in Savage et al. (2013).

A comparison of the MetUM settings for all three configurations described above can be seen in Table A1.

\section{Experimental set-up}

In this section, a description of the experimental set-up for modelling present-day air quality using the configurations of MetUM is provided, covering meteorological lower boundary conditions, emissions, upper boundary conditions, and lateral boundary conditions.

\subsection{Model simulations and model calibration}

Both the GCCM and the RCCM were initialized using meteorological fields from a pre-existing 20-year simulation of the standard HadGEM3 configuration. The simulations for both these model configurations cover a total period of 6 model years representative of the decade centred around the year 2000, for both meteorology and emissions. The first year is considered as an additional spin-up and the last 5 years are used in the analysis. The GCCM was used to produce the offline lateral boundary conditions (LBCs) at 6-hourly intervals to drive the RCCM, together with the emissions and upper and lower boundary conditions described below. LBCs include meteorological drivers (3-D winds, air temperature, air density, Exner pressure, humidity, and cloudiness), important chemical tracers from UKCA-ExtTC $\left(\mathrm{O}_{3}, \mathrm{NO}\right.$, nitrogen dioxide $\left(\mathrm{NO}_{2}\right), \mathrm{HNO}_{3}$, dinitrogen pentoxide $\left(\mathrm{N}_{2} \mathrm{O}_{5}\right), \mathrm{H}_{2} \mathrm{O}_{2}$, $\mathrm{CH}_{4}, \mathrm{CO}, \mathrm{HCHO}, \mathrm{C}_{2} \mathrm{H}_{6}, \mathrm{C}_{3} \mathrm{H}_{8}, \mathrm{CH}_{3} \mathrm{COCH}_{3}$, and peroxy acetyl nitrate (PAN)), gas-phase aerosol precursors $\left(\mathrm{SO}_{2}\right.$, DMS) and aerosols (dust, sulfate, nitrate, soot, FFOC, and BB) from CLASSIC. In turn, the RCCM produced meteorological and composition LBCs required to drive the AQUM national-scale air quality model. Simulations with AQUM were initialized from the last month of the first year of the RCCM and were continued for 5 model years by applying the LBCs supplied by the RCCM offline at 6-hourly intervals. The chemical and aerosol species provided in the LBCs are dust, $\mathrm{SO}_{2}, \mathrm{DMS}, \mathrm{SO}_{4}$, soot, OCFF, nitrate, $\mathrm{O}_{3}, \mathrm{NO}, \mathrm{NO}_{2}$, $\mathrm{N}_{2} \mathrm{O}_{5}, \mathrm{HONO}_{2}, \mathrm{H}_{2} \mathrm{O}_{2}, \mathrm{CH}_{4}, \mathrm{CO}, \mathrm{HCHO}, \mathrm{C}_{2} \mathrm{H}_{6}, \mathrm{PAN}$, and $\mathrm{C}_{3} \mathrm{H}_{8}$.

For lower boundary conditions the GCCM used monthly mean distributions of sea surface temperature (SST) and sea ice cover (SIC), derived for the present day (1995-2005) from transient coupled atmosphere-ocean simulations (Jones et al., 2011) of the HadGEM2-ES model (Collins et al., 2011). It should be pointed out here that the entire set-up is intended to represent a decadal climatological mean state of near present-day conditions encompassing the period from
1995 to 2005 and centred on the year 2000. This particularly applies to the meteorological drivers (sea surface temperature, SSTs, and sea ice cover) and the anthropogenic emissions of pollutants. The latter will be discussed in more detail in Sect. 3.2. The vegetation distribution for each of the simulations was prescribed using the simulated vegetation averaged for the same decade from this transient climate run, on which crop area, as given in the 5th Coupled Model Intercomparison Project (CMIP5) land use maps (Riahi et al., 2007; Hurtt et al., 2011), was superimposed. The same present-day SST and SIC climatologies developed for the GCCM were regridded to the RCCM and the AQUM domains using a simple linear regridding algorithm.

The GCCM was calibrated against $\mathrm{O}_{3}$ measurements from the monitoring station located at Mace Head Atmospheric Research Station in western Ireland at $53.3^{\circ} \mathrm{N}$ and $9.9^{\circ} \mathrm{W}$. It is part of the Automatic Urban and Rural Monitoring Network (AURN) which is run by a number of institutions coordinated by Defra. The Mace Head monitoring station is representative of rural background conditions. Model output has been compared to the annual cycle of monthly mean $\mathrm{O}_{3}$ which is based on a multi-year climatology of observed near-surface $\mathrm{O}_{3}$ concentrations. The parameterized $\mathrm{O}_{3}$ surface dry deposition was used to perform the calibration as the model shows very high sensitivity to deposition. The model has been optimized to reproduce both the magnitude and seasonal cycle of $\mathrm{O}_{3}$ at the Mace Head site in the global model domain as closely as possible by varying the $\mathrm{O}_{3}$ surface dry deposition flux within its uncertainty limits. An increase in the $\mathrm{O}_{3}$ dry deposition by $20 \%$ yielded the best agreement, with respect to both $\mathrm{O}_{3}$ monthly mean surface concentration and seasonal cycle, with the observed climatology at the Mace Head station, which is representative of the $\mathrm{O}_{3}$ background concentration in the lower troposphere, in the study area.

As the RCCM uses the same code base as the GCCM, this calibration is inherited by the former automatically. The model calibration has been applied to optimize consistency between the individual configurations in the global-tonational model nesting chain.

Due to the different chemistry scheme used in AQUM, the calibration used by the GCCM was not incorporated into AQUM as the RAQ scheme has been developed with performance over the UK as its main focus. This is unlike the GCCM, where performance usually has to be taken into account over the entire globe, which may lead to worse performance in some regions such as the UK. The calibration was performed to ensure that the best possible boundary conditions are applied to the innermost, national-scale domain. Mace Head station was chosen because it is representative of the large-scale background tropospheric ozone level in the study area and includes the impact of transcontinental influx of pollution from North America. 


\subsection{Emissions}

A consistent set of emissions has been used for all three model configurations through using the same source data, but then regridding to the required resolution for each model.

The emissions of reactive gases and aerosols from anthropogenic and biomass burning sources used in this study are based on the dataset used for CMIP5 simulations and described by Lamarque et al. (2010). The models are all driven by decadal mean present-day emissions from CMIP5, representative of the decade centred on 2000. An example of the emissions for the different domains is given for NO in Fig. 2, while a full set of emission totals can be seen in Tables A2, $\mathrm{A} 3$, and $\mathrm{A} 4$.

UKCA-ExtTC takes into account emissions for 17 of its chemical species: nitrogen oxides $\left(\mathrm{NO}_{x}=\mathrm{NO}+\mathrm{NO}_{2}\right)$, carbon monoxide (CO), hydrogen $\left(\mathrm{H}_{2}\right)$, methanol, formaldehyde, acetaldehyde and higher aldehydes, acetone $\left(\mathrm{CH}_{3} \mathrm{COCH}_{3}\right)$, methyl ethyl ketone, ethane $\left(\mathrm{C}_{2} \mathrm{H}_{6}\right)$, propane $\left(\mathrm{C}_{3} \mathrm{H}_{8}\right)$, butanes and higher alkanes, ethene, propene and higher alkenes, isoprene, (mono)terpenes, and aromatic species. Of these butanes and higher alkanes, propene and higher alkenes, terpenes, and aromatics are treated as lumped species. Surface emissions are prescribed in most cases. The only exception is the emission of biogenic volatile organic compounds (BVOCs) which are calculated interactively in JULES using the iBVOC emission model (Pacifico et al., 2011). The emission of biogenic terpenes, methanol, and acetone follows the model described in Guenther et al. (1995). As summarized in Table A3, global annual total emissions of biogenic isoprene and monoterpenes interactively computed with the iBVOC model of, for instance, $480 \mathrm{Tg}(\mathrm{C}) \mathrm{yr}^{-1}$ and of $95 \mathrm{Tg}(\mathrm{C}) \mathrm{yr}^{-1}$ are in reasonably good agreement with most other state-of-science interactive biogenic VOC emission models (e.g. Lathière et al., 2005; Guenther et al., 2006; Arneth et al., 2007; Müller et al., 2008; Messina et al., 2016) and global bVOC emission inventories (e.g. Arneth et al., 2008; Sindelarova et al., 2014). A detailed evaluation of the model performance is presented in Pacifico et al. (2011).

Emissions of $\mathrm{NO}_{x}$ from lightning are taken into account in UKCA. Lightning $\mathrm{NO}_{x}$ emissions are calculated interactively at every time step, based on the distribution and frequency of lightning flashes following Price and Rind (1992), Price and Rind (1993), and Price and Rind (1994). In this parametrization the lightning flash frequency is proportional to the height of the convective cloud top in all the models. For cloud-to-ground (CG) flashes lightning $\mathrm{NO}_{x}$ emissions are added below $500 \mathrm{hPa}$, distributed from the surface to the $500 \mathrm{hPa}$ level, while $\mathrm{NO}_{x}$ emissions resulting from intracloud (IC) flashes are distributed from the $500 \mathrm{hPa}$ level up to the convective cloud top. The emission magnitude is related to the discharge energy where CG flashes are 10 times more energetic than IC flashes (Price et al., 1997). The scheme implemented in the GCCM produces a total global emission source of around $7 \mathrm{Tg}(\mathrm{N}) \mathrm{yr}^{-1}$, which is in good agreement with the literature (cf. e.g. Schumann and Huntrieser, 2007).

Soil-biogenic $\mathrm{NO}_{x}$ emissions are taken from the monthly mean distributions from the Global Emissions Inventory Activity (http://www.geiacenter.org/inventories/present. html), which are based on the global empirical model of soilbiogenic $\mathrm{NO}_{x}$ emissions of Yienger and Levy II (1995) giving a global annual total of $5.6 \mathrm{Tg}(\mathrm{N}) \mathrm{yr}^{-1}$.

For $\mathrm{CH}_{4}$, the UKCA model can be run by prescribing surface emissions or prescribing either a constant or timevarying global mean surface concentration. For the simulations being evaluated here, a time-invariant $\mathrm{CH}_{4}$ concentration of $1760 \mathrm{ppbv}$ was prescribed at the surface.

The sea salt and mineral dust emissions are computed interactively at each model time step based on instantaneous near-surface wind speeds (Jones et al., 2001; Woodward, 2001). Mineral dust is a fully prognostic, advected species but, as mentioned in Sect. 2.1, sea salt is not advected and makes no contribution to model aerosol concentrations over land.

Similarly the ocean DMS emissions are computed based on wind speed, temperature, and climatological ocean DMS concentrations from Kettle et al. (1999), using the sea-air exchange flux scheme from Wanninkhof (1992).

Emissions for AQUM are derived by re-gridding emissions from the regional model to the required $0.11^{\circ}$ resolution. The ExtTC and RAQ chemistry schemes emit different anthropogenic VOC species; consequently, some conversion is required. Our approach is to sum the anthropogenic VOC emission from ExtTC and apportion this total according to the values given in Table 1 . These values were derived using the tabulated VOC emission fraction data over the UK for 2006 given by Dore et al. (2008). A consequence of this is that for some species the emission total in the smaller AQUM domain exceeds that of the larger RCCM domain. However, the total VOC emitted is conserved between AQUM and the corresponding part of the RCCM domain. For biogenic isoprene emissions, AQUM uses an offline, monthly varying climatology which was derived from the online isoprene emission fluxes generated by the RCCM. A diurnal cycle is applied to account for daylight hours.

\subsection{AQUM with higher-resolution emissions}

Following an initial evaluation of results, an additional model run was also carried out using AQUM. This run was identical to the main AQUM run (using the same RCCM LBCs), with the exception of the anthropogenic emissions used. A new set of the latter was produced based on the higher-resolution datasets which AQUM uses for its operational air quality forecast; these are described further in Savage et al. (2013). Figure 2 shows the impact of these emissions for NO. The highest-resolution input data to these emissions are at $1 \mathrm{~km}$ over the UK, although regridded to the $12 \mathrm{~km}$ resolution required by AQUM. These are based on 2006 emissions, but 
Table 1. VOC split to convert total emitted VOCs from ExtTC to RAQ emitted VOCs. These factors sum to 1.0.

\begin{tabular}{lr}
\hline Species & Conversion factor \\
\hline $\mathrm{HCHO}$ & 0.055 \\
$\mathrm{C}_{2} \mathrm{H}_{6}$ & 0.156 \\
$\mathrm{CH}_{3} \mathrm{CHO}$ & 0.015 \\
$\mathrm{C}_{3} \mathrm{H}_{8}$ & 0.110 \\
$\mathrm{CH}_{3} \mathrm{COCH}$ & 0.078 \\
$\mathrm{CH}_{3} \mathrm{OH}$ & 0.116 \\
$\mathrm{C}_{2} \mathrm{H}_{4}$ & 0.079 \\
$\mathrm{C}_{3} \mathrm{H}_{6}$ & 0.034 \\
$\mathrm{C}_{4} \mathrm{H}_{10}$ & 0.238 \\
toluene & 0.095 \\
o-xylene & 0.024 \\
\hline
\end{tabular}

the total emission has been rescaled to match the year 2000 decadal mean areal totals given by Lamarque et al. (2010) (as described in Sect. 3.2). For the remainder of the paper, this additional run will be referred to as AQUM-h.

\subsection{Upper boundary conditions}

While the chemistry is calculated interactively up to the model top in each configuration, upper boundary conditions are applied at the top of each model domain to account for missing stratospheric processes such as those related to $\mathrm{CH}_{4}$ oxidation and bromine and chlorine chemistry. These boundary conditions are described in detail in O'Connor et al. (2014) and are only briefly discussed here. For $\mathrm{O}_{3}$, the field used in the radiation scheme by MetUM in the absence of interactive chemistry is used to overwrite the modelled $\mathrm{O}_{3}$ field in all model levels that are $3-4 \mathrm{~km}$ above the diagnosed tropopause (Hoerling et al., 1993). For stratospheric odd nitrogen species $\left(\mathrm{NO}_{y}\right)$, a fixed $\mathrm{O}_{3}$ to $\mathrm{HNO}_{3}$ ratio of $1.0 / 1000.0 \mathrm{~kg}(\mathrm{~N}) / \mathrm{kg}\left(\mathrm{O}_{3}\right)$ from Murphy and Fahey (1994) is applied to $\mathrm{HNO}_{3}$ in the same vertical domain. Finally, for $\mathrm{CH}_{4}$, an additional removal term is applied in the three uppermost levels of the model. This $\mathrm{CH}_{4}$ loss term was calculated in $\mathrm{O}^{\prime}$ Connor et al. (2014) to be $50 \pm 10 \mathrm{TgCH}_{4} \mathrm{yr}^{-1}$ in a global configuration.

\section{Results}

Our aim is to evaluate the air pollutant concentration output from the RCCM and AQUM simulations using different datasets representative of the true air quality in the UK. In this way, we also aim to assess the potential for improving modelled air pollutant concentrations by increasing model spatial resolution. The datasets we use include (i) in situ observations of hourly air pollutant concentrations from the UK Automatic Urban and Rural Network (AURN) and (ii) annual mean surface pollutant concentrations produced by the Pollution Climate Mapping (PCM) model which also takes

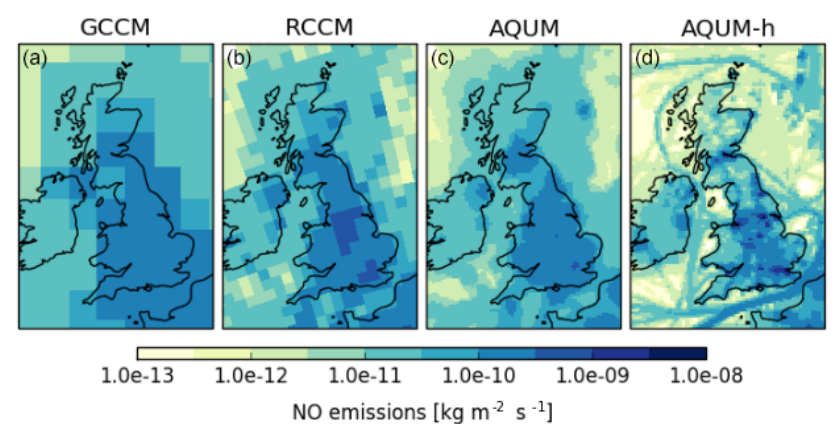

Figure 2. NO emissions for all models: GCCM (a), RCCM (b), AQUM (c), and the higher-resolution emissions run (AQUM-h) (d).

into account observations described by Brookes et al. (2013). This model produces gridded fields at a spatial resolution of $1 \mathrm{~km}$ over the whole of the UK.

Another aspect of the analysis undertaken is to employ two different approaches to model assessment. The first uses standard verification metrics such as bias based on site-specific comparisons averaged over the 5-year modelled period. The second approach uses neighbourhood verification techniques which consider the area surrounding a particular point and thus allow for some mismatch in the spatial positioning of elevated pollutant values, thereby avoiding the well-known “double penalty" problem (Mittermaier, 2014).

We begin with a qualitative comparison of the GCCM against the two limited-area models in order to illustrate the need for improved resolution over that of the GCCM for air quality applications.

\subsection{Comparison to GCCM}

Figure 3 compares UK monthly mean $\mathrm{NO}_{2}$ concentrations for June calculated from runs of the GCCM, RCCM, AQUM, and AQUM-h models. In the GCCM plot the resolution is wholly insufficient to realistically represent the elevated $\mathrm{NO}_{2}$ levels around the UK urban centres (London, West Midlands, Greater Manchester, West Yorkshire, Edinburgh) and in the busiest shipping lanes and ports (English Channel, Bristol Channel, Southampton, Liverpool). The representation improves qualitatively as we move to the right in this plot. It can clearly be seen that higher-resolution modelling is essential for providing realistic pollutant representations at more localized spatial scales.

\subsection{Comparison against in situ observations}

In this section we compare results from the RCCM, AQUM, and AQUM-h simulations with suitable averages derived from observations from the UK Automatic Urban and Rural Network (AURN, https://uk-air.defra.gov.uk/networks/ network-info?view=aurn) for 2001-2005. Note that the years here refer only to the observation time series and have no intrinsic meaning for the model simulations. As discussed in 


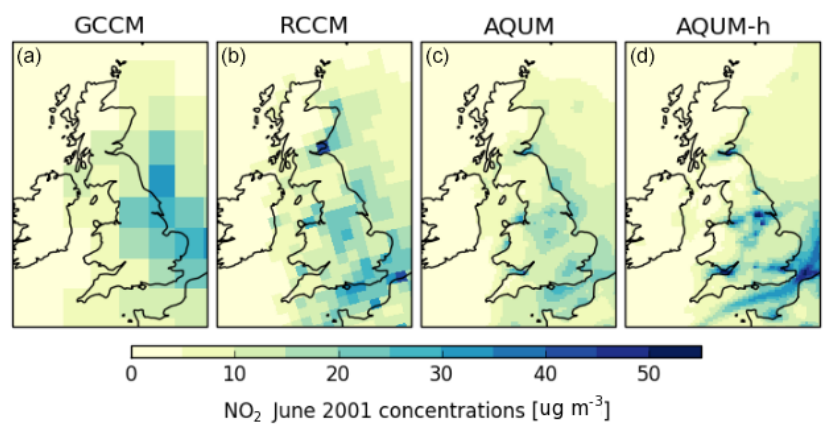

Figure 3. Monthly mean $\mathrm{NO}_{2}$ concentrations over the UK for June for the four different model runs. From left to right: GCCM, RCCM, AQUM, AQUM-h.

Sects. 3.1 and 3.2, the simulations represent climatological mean states representative of the decade from 1995 to 2005 and centred on the year 2000. We compare the model to the AURN 2001-2005 observational record because it represents the most complete record for the selected period available. The individual model years do not correlate with the corresponding years in the observational record. We performed the multi-year simulations to obtain a statistical sample to investigate interannual variability to some degree. The variability, of course, will be reduced due to the fact that composition and climate have been decoupled, but there is still variability in the atmospheric chemistry. From AURN we only consider "background" sites which include the site classifications of remote, rural, suburban, and urban background. We are therefore excluding sites which we expect to be un-representative of a large area, such as roadside or industrial sites. As the models are driven by climatological meteorology, we do not expect the model results to match the hourly AURN observations; hence, we compare values averaged over the 5-year period with corresponding averages derived from the hourly observations.

\subsection{1 $\mathrm{NO}_{2}$}

Figure $4 \mathrm{a}$ shows a frequency distribution of hourly observed concentrations of $\mathrm{NO}_{2}$ with corresponding frequency distributions for modelled concentrations from the RCCM, AQUM, and AQUM-h configurations. It is clear that the AQUM-h model distribution more closely matches the observed distribution than the other model configurations, illustrating the importance of increased spatial resolution and emissions for this pollutant. Corresponding statistical measures of model skill are given in Table 2. The bias in RCCM and AQUM against AURN observations is -4.76 and $-5.47 \mu \mathrm{g} \mathrm{m}^{-3}$, respectively, but is reduced to $-0.80 \mu \mathrm{g} \mathrm{m}^{-3}$ in AQUM-h. In Table 2 a comparison of the percentage of observations/model values greater than the $65.0 \mu \mathrm{g} \mathrm{m}^{-3}$ threshold is also included; it illustrates that AQUM-h simulates observed frequencies of higher $\mathrm{NO}_{2}$ concentrations well, mak- ing it better suited to calculating health burdens due to elevated levels of $\mathrm{NO}_{2}$ (e.g. Pannullo et al., 2017). However, shown in Fig. 5a is a comparison of the seasonal cycle of observed and modelled $\mathrm{NO}_{2}$ concentrations, averaged over all AURN sites considered. This shows that none of the models is able to fully capture the seasonal cycle of $\mathrm{NO}_{2}$, with wintertime modelled concentrations biased low, while the RCCM and AQUM straddle the observed concentrations during summer. This is possibly due to the poor representation of the monthly variation of emissions over the UK in the global model which is then inherited by the higher resolution models. However, other processes such as boundary layer mixing or chemistry could equally contribute. Further work would be required to elucidate this clearly.

\subsection{2 $\mathrm{O}_{3}$}

Relevant statistics are given in Table 2, while a frequency distribution plot, showing the distribution of hourly $\mathrm{O}_{3}$ concentrations over the entire period for models and observations, is shown in Fig. $4 \mathrm{~b}$ and the seasonal cycle is given in Fig. 5b. The latter plot illustrates that the pattern of the seasonal cycle of $\mathrm{O}_{3}$ is captured reasonably well; however, the modelled spring-summer maximum persists too long and does not replicate the gradual decline in monthly mean concentrations as indicated by observations. This has implications for the use of modelled $\mathrm{O}_{3}$ to quantify health impacts from long-term exposure to $\mathrm{O}_{3}$ during warmer months, as indicated by studies in North America (WHO, 2013b; COMEAP, 2015). In the frequency distribution plots in Fig. 4b, it can be seen that all models are able to reproduce the shape of the observed distribution quite well but differ in their most frequent concentration, corresponding to different model biases. The RCCM exhibits the smallest bias against observations of $+6.23 \mu \mathrm{g} \mathrm{m}^{-3}$, and AQUM the greatest at $+9.96 \mu \mathrm{g} \mathrm{m}^{-3}$ (see Table 2). However, the RCCM used an offline photolysis scheme (O'Connor et al., 2014), whilst both configurations of AQUM used the interactive Fast-J scheme (Wild et al., 2000). Given the different photolysis schemes used, a sensitivity experiment for a single month of July was carried out, in which AQUM-h was re-run with offline photolysis. The $\mathrm{O}_{3}$ bias for this month is $7.33 \mu \mathrm{g} \mathrm{m}^{-3}$ for the RCCM, $22.48 \mu \mathrm{g} \mathrm{m}^{-3}$ for AQUM, and $13.95 \mu \mathrm{g} \mathrm{m}^{-3}$ for AQUM-h. Although the photolysis rates relevant to $\mathrm{O}_{3}, j\left(\mathrm{NO}_{2}\right) \rightarrow \mathrm{NO}$, and $j\left(\mathrm{O}_{3}\right) \rightarrow \mathrm{O}^{1} \mathrm{D}$ are known to be biased low in the offline photolysis scheme relative to both observations and online photolysis (Telford et al., 2013), the modelled $\mathrm{O}_{3}$ bias in AQUM-h is reduced to $+6.99 \mu \mathrm{g} \mathrm{m}^{-3}$ with the offline scheme, which is marginally better than the RCCM. However, the sensitivity of surface $\mathrm{O}_{3}$ to the choice of photolysis scheme found here differs from two previous studies (O'Connor et al., 2014; Telford et al., 2013). Both of these studies found that $\mathrm{O}_{3}$ decreased in the Northern Hemisphere by less than $5 \%$ when switching from offline to online photolysis and, indeed, the changes in the tropospheric 
Table 2. Statistics comparing modelled air pollutant concentrations to AURN observations, for the period of the observational record 1 January 2001-31 December 2005 (for the correlation between model years and the observational record compare the discussion in the text).

\begin{tabular}{|c|c|c|c|c|}
\hline & & RCCM & AQUM & AQUM-h \\
\hline \multirow[t]{4}{*}{$\mathrm{NO}_{2}$} & Number of sites & 65 & 65 & 65 \\
\hline & $\operatorname{Bias}\left(\mu \mathrm{g} \mathrm{m}^{-3}\right)$ & -4.76 & -5.47 & -0.80 \\
\hline & $\%$ Observations $>$ threshold $\left(=65.0 \mu \mathrm{m}^{-3}\right)$ & 6.21 & 6.21 & 6.21 \\
\hline & $\%$ Model $>$ threshold $\left(=65.0 \mu \mathrm{g} \mathrm{m}^{-3}\right)$ & 1.86 & 2.07 & 5.64 \\
\hline \multirow[t]{4}{*}{$\mathrm{O}_{3}$} & Number of sites & 65 & 65 & 65 \\
\hline & $\operatorname{Bias}\left(\mu \mathrm{g} \mathrm{m}^{-3}\right)$ & 6.23 & 13.94 & 9.96 \\
\hline & $\%$ Observations $>$ threshold $\left(=100.0 \mu \mathrm{g} \mathrm{m}^{-3}\right)$ & 2.39 & 2.39 & 2.39 \\
\hline & $\%$ Model $>$ threshold $\left(=100.0 \mu \mathrm{g} \mathrm{m}^{-3}\right)$ & 3.18 & 8.54 & 7.07 \\
\hline \multirow[t]{4}{*}{$\mathrm{PM}_{10}$} & Number of sites & 40 & 40 & 40 \\
\hline & $\operatorname{Bias}\left(\mu \mathrm{g} \mathrm{m}^{-3}\right)$ & -12.45 & -13.32 & -14.41 \\
\hline & $\%$ Observations $>$ threshold $\left(=50.0 \mu \mathrm{g} \mathrm{m}^{-3}\right)$ & 4.18 & 4.18 & 4.18 \\
\hline & $\%$ Model $>$ threshold $\left(=50.0 \mu \mathrm{g} \mathrm{m}^{-3}\right)$ & 0.99 & 0.87 & 0.85 \\
\hline \multirow[t]{4}{*}{$\mathrm{PM}_{2.5}$} & Number of sites & 2 & 2 & 2 \\
\hline & $\operatorname{Bias}\left(\mu \mathrm{g} \mathrm{m}^{-3}\right)$ & 0.33 & -0.75 & -2.46 \\
\hline & $\%$ Observations $>$ threshold $\left(=35.0 \mu \mathrm{g} \mathrm{m}^{-3}\right)$ & 1.08 & 1.08 & 1.08 \\
\hline & $\%$ Model $>$ threshold $\left(=35.0 \mu \mathrm{g} \mathrm{m}^{-3}\right)$ & 3.93 & 3.11 & 2.40 \\
\hline \multirow[t]{4}{*}{$\mathrm{SO}_{2}$} & Number of sites & 49 & 49 & 49 \\
\hline & $\operatorname{Bias}\left(\mu \mathrm{g} \mathrm{m}^{-3}\right)$ & 2.61 & 1.44 & 1.59 \\
\hline & $\%$ Observations $>$ threshold $\left(=25.0 \mu \mathrm{g} \mathrm{m}^{-3}\right)$ & 2.89 & 2.89 & 2.89 \\
\hline & $\%$ Model $>$ threshold $\left(=25.0 \mu \mathrm{g} \mathrm{m}^{-3}\right)$ & 3.98 & 3.71 & 5.31 \\
\hline
\end{tabular}

$\mathrm{O}_{3}$ budget were consistent between the two studies. In addition, O'Connor et al. (2014) found no significant change in modelled $\mathrm{O}_{3}$ evident at $\mathrm{NH}$ mid-latitude sites (e.g. Mace Head). However, both O'Connor et al. (2014) and Telford et al. (2013) were global studies rather than the regional scale considered here. Another conflicting factor is the calibration which has been applied to the RCCM for the $\mathrm{O}_{3}$ dry deposition, which would have an impact on the $\mathrm{O}_{3}$ concentrations, although this would have impacted AQUM through the LBCs. This calibration was not included in the papers described above, which may help to explain the conflicting results. Consequently, these factors make it difficult to isolate and quantify the impact of the higher resolution third nest on model performance.

\subsection{3 $\quad \mathrm{PM}_{10}$}

Relevant statistics are given in Table 2, while a frequency distribution plot, showing the distribution of hourly $\mathrm{PM}_{10}$ values over the entire period for models and observations, is shown in Fig. 4c.

For $\mathrm{PM}_{10}$, none of the models are able to reproduce the shape of the observed distribution, and there is a significant negative bias across all the model configurations (between -12.45 and $-14.41 \mu \mathrm{g} \mathrm{m}^{-3}$ ), with AQUM-h exhibiting the poorest performance. Poor modelling performance for $\mathrm{PM}_{10}$ is a common feature of many global composition and re- gional air quality models (e.g. Colette et al., 2011; Im et al., 2015) and is often attributed to the unreliability of primary emissions of coarse component aerosol, both from anthropogenic and biogenic sources. In our simulations the lack of sea salt in modelled values over land points plays a significant role in this underprediction. Putaud et al. (2010) estimate that over north-western Europe sea salt contributes on average between $7 \%$ (kerbside sites) and $12 \%$ (rural sites) of the observed annual mean $\mathrm{PM}_{10}$. In periods of strong winds and at sites close to the coast downwind of the sea, values may be considerably higher. A related consequence of our lack of inclusion of sea salt is that our aerosol modelling does not include sodium nitrate, and so this coarse component of secondary aerosol is also missing from our estimates. These underpredictions could potentially affect the quantification of health effects due to short-term and long-term exposure of $\mathrm{PM}_{10}$, as documented by the WHO (2013b).

\subsection{4 $\mathrm{PM}_{2.5}$}

Relevant statistics are given in Table 2, while a frequency distribution plot, showing the distribution of hourly $\mathrm{PM}_{2.5}$ values over the entire period for models and observations, is shown in Fig. 4d.

For the finer $\mathrm{PM}_{2.5}$ component of aerosol, the models perform significantly better in capturing the shape of the observed distribution than for $\mathrm{PM}_{10}$; there is a small 


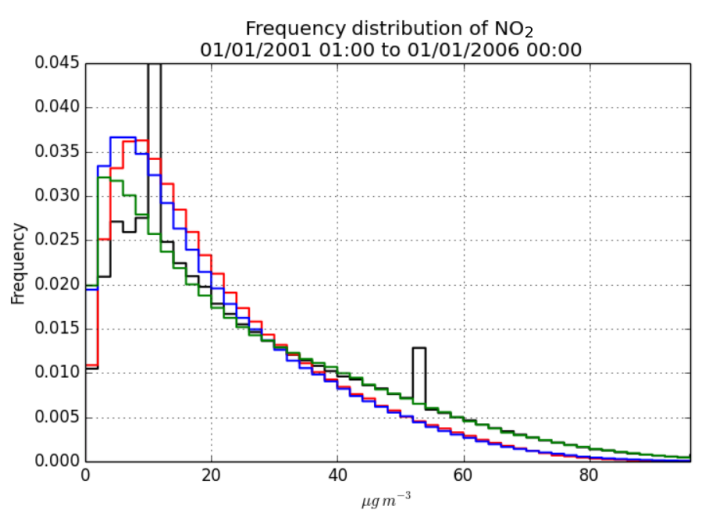

(a)

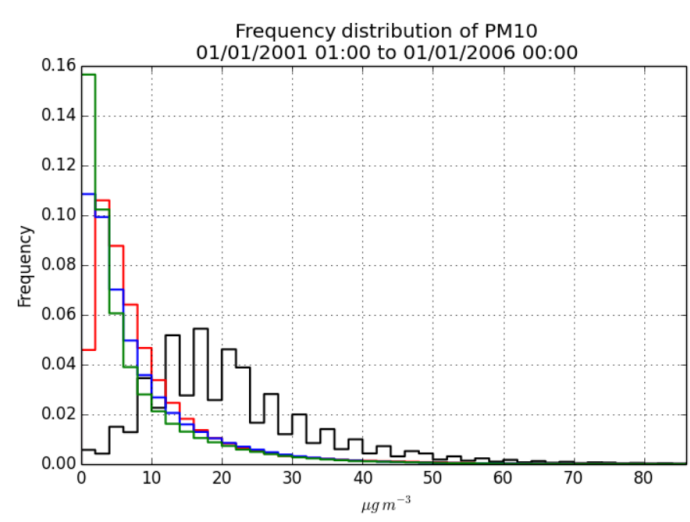

(c)

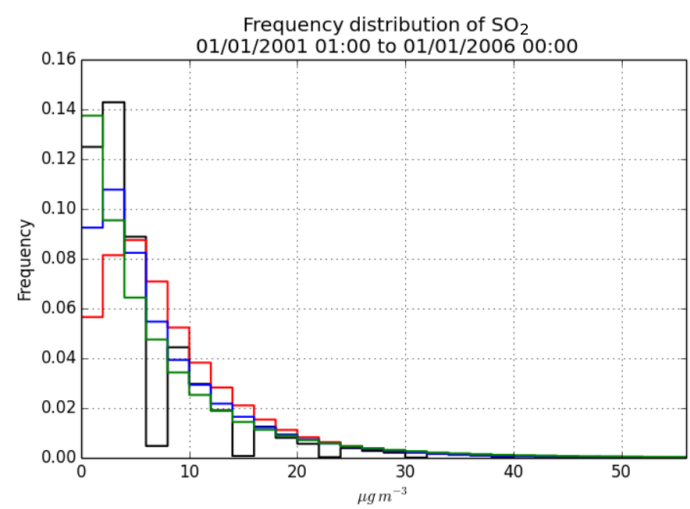

(e)

Figure 4. Frequency distribution of the main pollutants: (a) $\mathrm{NO}_{2}$, (b) $\mathrm{O}_{3}$, (c) $\mathrm{PM}_{10}$, (d) $\mathrm{PM}_{2.5}$, and (e) $\mathrm{SO}_{2}$. Observations are shown in black, RCCM in red, AQUM in blue, and AQUM-h in green.

positive bias for $\mathrm{PM}_{2.5}$ in the RCCM $\left(+0.33 \mu \mathrm{g} \mathrm{m}^{-3}\right)$, whereas AQUM becomes slightly negative $\left(-0.75 \mu \mathrm{g} \mathrm{m}^{-3}\right)$ and AQUM-h more negative still $\left(-2.46 \mu \mathrm{g} \mathrm{m}^{-3}\right)$.

However, the observed frequency distribution is only based on two background observational sites available for $\mathrm{PM}_{2.5}$ in the UK for the 2001-2005 time period. The introduction of $\mathrm{PM}_{2.5}$ monitoring stations in the UK increased significantly from 2009 and we explored the possibility of us-

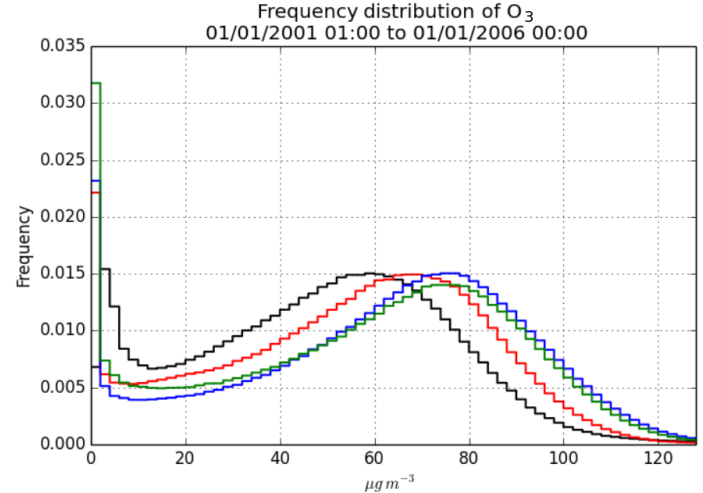

(b) $\square$ Obs $\square$ RCCM $\square$ AQUM $\square$ AQUM-h

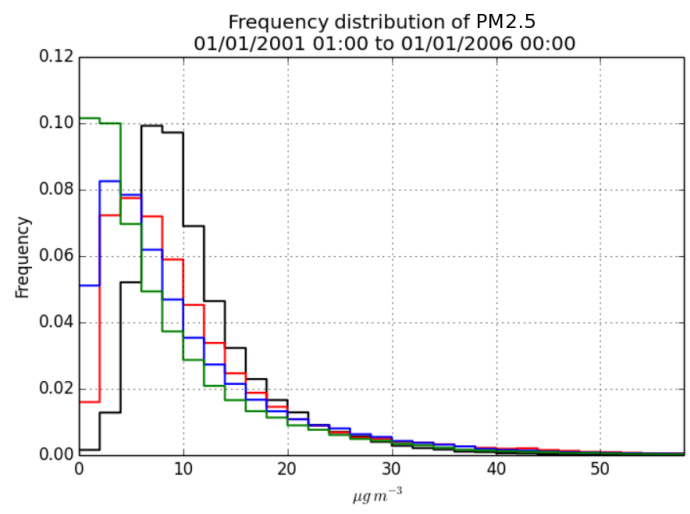

(d)

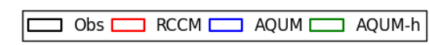

ing observations from 2011 to 2015 to generate a proxy for the 2001-2005 frequency distribution. However, we found that the $\mathrm{PM}_{10}$ distribution changed significantly over the 10 years and concluded that it was not valid to use the more recent $\mathrm{PM}_{2.5}$ observations in place of 2001-2005 observations. Consequently, due to the paucity of $\mathrm{PM}_{2.5}$ observations for the 2001-2005 time period against which to compare, for the 


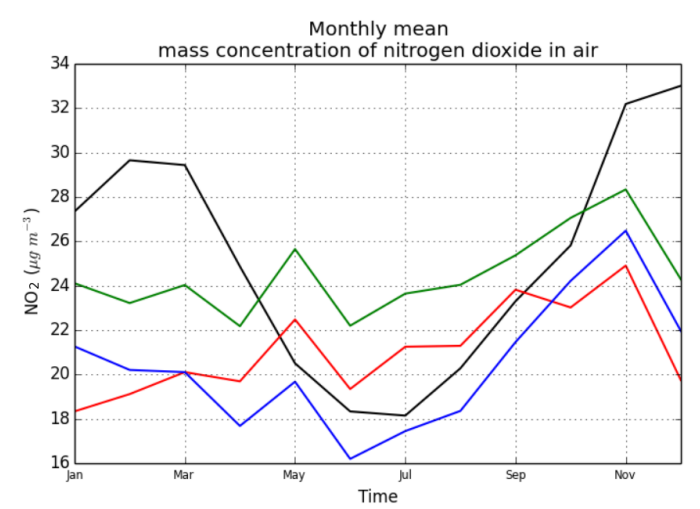

(a)

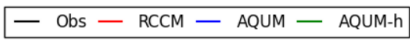

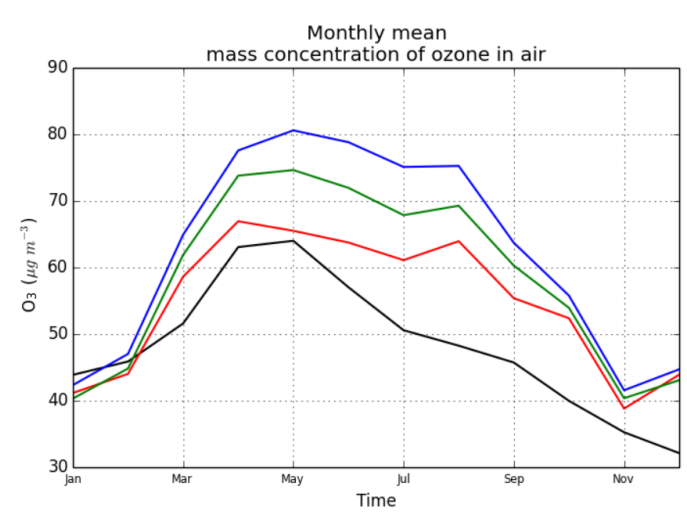

(b)

Figure 5. Monthly mean concentrations of (a) $\mathrm{NO}_{2}$ and (b) $\mathrm{O}_{3}$. Observations are shown in black, RCCM in red, AQUM in blue, and AQUM-h in green.

remainder of this paper, we shall no longer consider $\mathrm{PM}_{2.5}$ results.

\subsection{5 $\quad \mathrm{SO}_{2}$}

Relevant statistics are given in Table 2, while a frequency distribution plot, showing the distribution of hourly $\mathrm{SO}_{2}$ values over the entire period for models and observations, is shown in Fig. 4e.

For $\mathrm{SO}_{2}$, the model configurations exhibit similar distributions to the observed distribution, with generally positive biases of between +1.44 and $+2.61 \mu \mathrm{g} \mathrm{m}^{-3}$, with AQUM-h exhibiting the best performance.

\subsection{Comparison against PCM}

In order to assess the variation in the quality of modelled air pollutant concentrations between the different model configurations, it is necessary to consider full spatial fields rather than the site comparison afforded by in situ observations described in the preceding section. Therefore, it is essential to compare the models against a realistic spatial field and, for this purpose, we use fields derived from the PCM model, as described in Brookes et al. (2013). This sophisticated model combines information from a variety of sources, including emission inventories and observation datasets, to produce estimated annual mean surface pollutant concentrations on a $1 \mathrm{~km} \times 1 \mathrm{~km}$ grid over the entire UK for $\mathrm{NO}_{2}, \mathrm{SO}_{2}, \mathrm{PM}_{10}$, and $\mathrm{PM}_{2.5}$. The data are freely available at https://uk-air. defra.gov.uk/data/pcm-data. These results are widely used in the UK to provide the background pollutant concentrations for local air quality modelling studies and new site impact assessment studies. $\mathrm{O}_{3}$ is also modelled by PCM, but the output available is the number of days exceeding $120 \mu \mathrm{g} \mathrm{m} \mathrm{m}^{-3}$ (as required by the European Union ambient air quality directives (http://eur-lex.europa.eu/LexUriServ/LexUriServ. do?uri=OJ:L:2008:152:0001:0044:EN:PDF) rather than pol- lutant concentrations, and so cannot be used in our analysis. In view of the lack of AURN PM $_{2.5}$ observations (also used in deriving the PCM maps) during the period 2001-2005 (as described in Sect. 4.2.4), we have not considered $\mathrm{PM}_{2.5}$ in the following analysis.

PCM data for $\mathrm{NO}_{2}$ and $\mathrm{PM}_{10}$ are available for 20012005, while $\mathrm{SO}_{2}$ data are only available from 2002 onwards. A comparison (not shown) of the PCM against the in situ AURN observations as done for the models in Sect. 4.2 proved the PCM verifies better than any of the other models. PCM data from the available years were processed to produce 5-year means (4 years for $\mathrm{SO}_{2}$ ) for comparison with the similarly averaged model fields.

Comparisons between MetUM modelled annual mean concentrations and PCM annual mean concentrations are shown for $\mathrm{NO}_{2}, \mathrm{SO}_{2}$, and $\mathrm{PM}_{10}$ in Fig. 6. In these plots nearest neighbour regridding is used to interpolate the model fields and the PCM fields onto the $12 \mathrm{~km}$ AQUM grid. Spatial correlations have been calculated between the regridded model and PCM fields (only at valid PCM data points, i.e. UK land points) and are shown at the top of each figure.

For the primary pollutants of $\mathrm{NO}_{2}$ (Fig. 6a) and $\mathrm{SO}_{2}$ (Fig. 6b), there is an improvement in correlation with the PCM as we move from the RCCM to AQUM and finally AQUM-h: for $\mathrm{NO}_{2}$ the correlations are 0.822, 0.824, and 0.836 , respectively, while for $\mathrm{SO}_{2}$ the correlations are 0.664, 0.743 , and 0.761 , respectively. For $\mathrm{SO}_{2}$, the introduction or removal of strong point sources can influence the comparison via a calculated spatial correlation. This is apparent in the AQUM-h plots in Fig. 6b, where two new strong point sources in south-eastern England are present in the 2006 data used to generate the AQUM-h emissions. These modest increases in correlation with PCM (as our proxy for "truth"), as model resolution increases, illustrate the benefits of increased resolution modelling, with respect to both the model grid and the underlying emissions data, in better capturing 


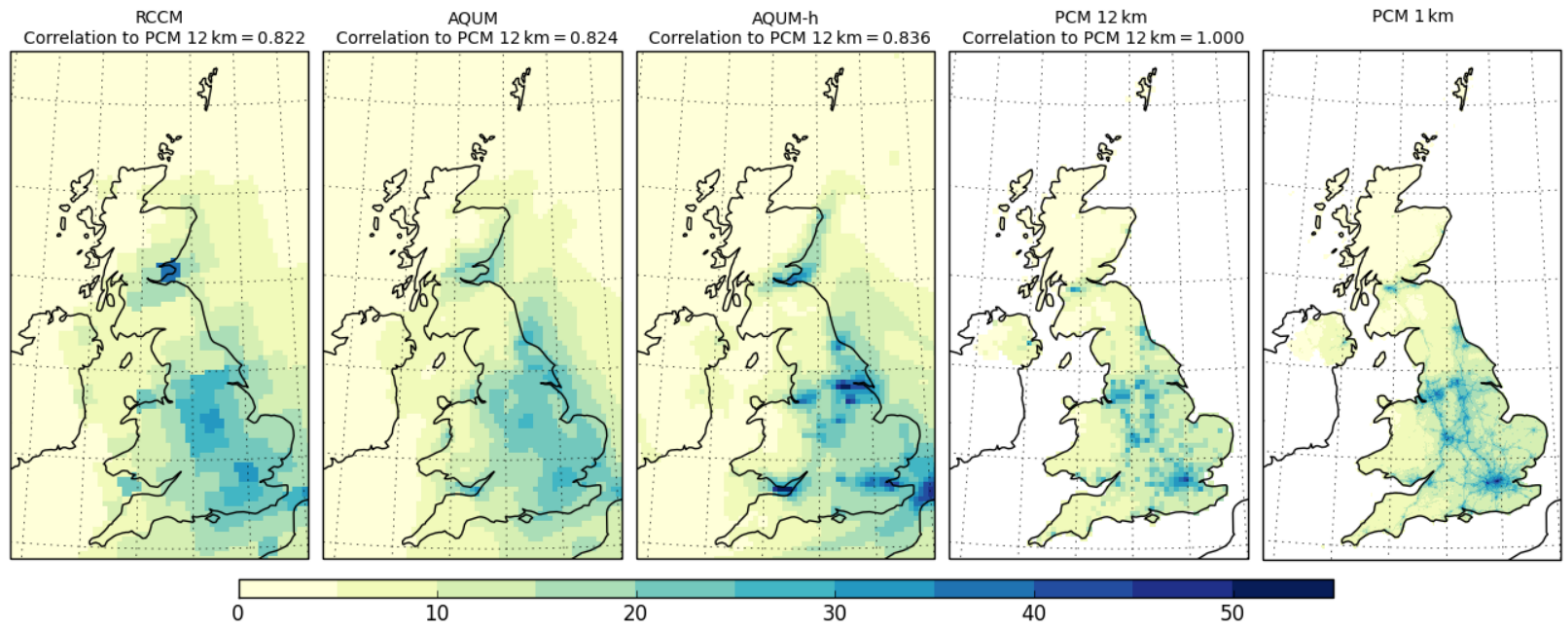

(a)

$\mathrm{NO}_{2}\left[\mathrm{ug} \mathrm{m}^{-3}\right.$ ]

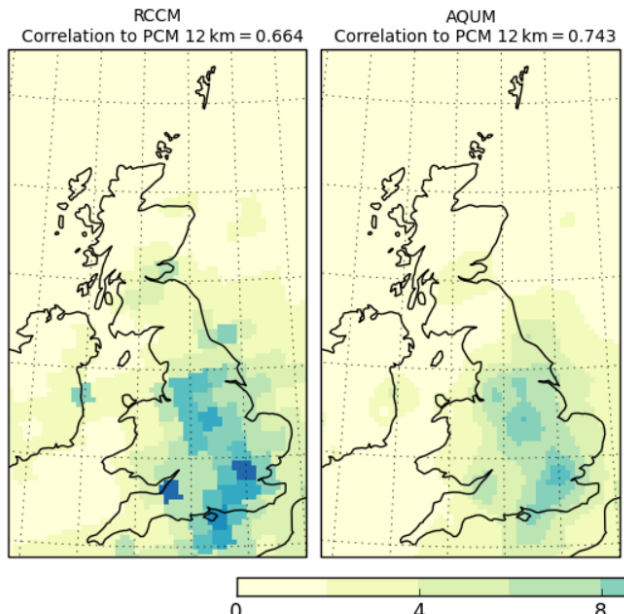

AQUM-h

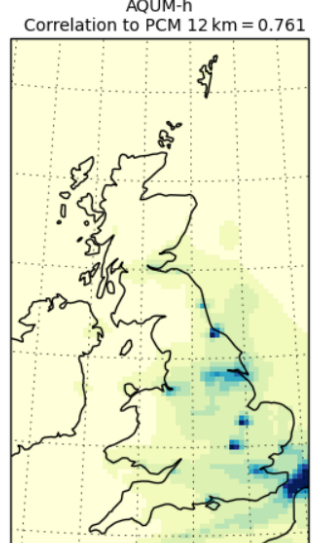

PCM $12 \mathrm{~km}$

PCM $1 \mathrm{~km}$
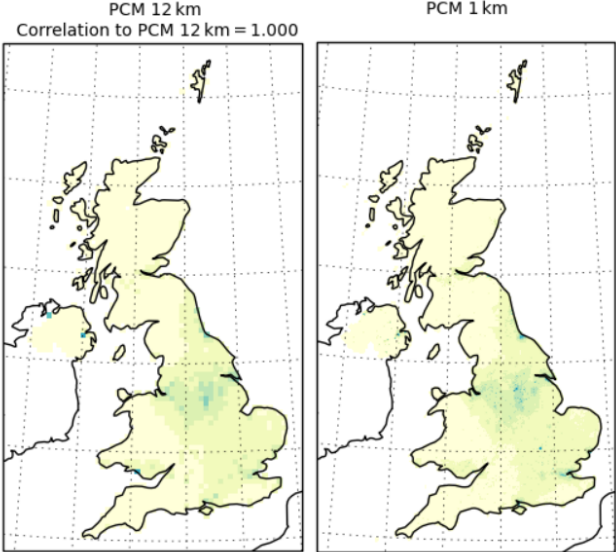

(b)

$\mathrm{SO}_{2}$ [ug $\mathrm{m}^{-3}$ ]

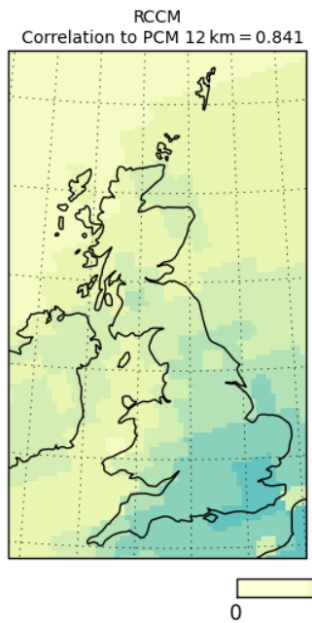

(c)
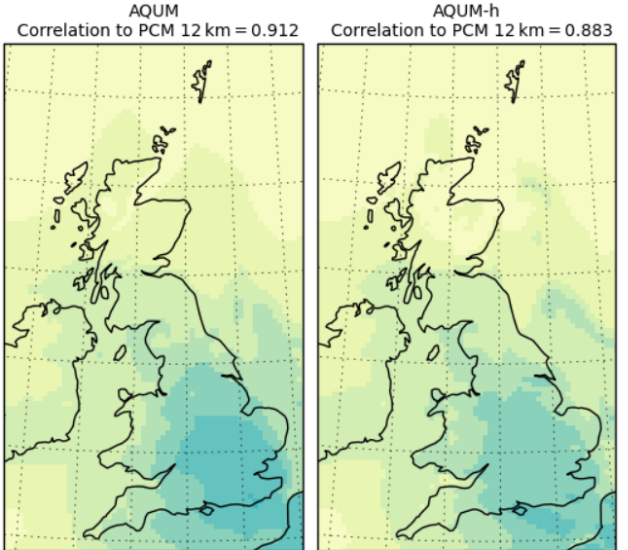

Correlation $12 \mathrm{~km}$ to $\mathrm{kCM} 12 \mathrm{~km}=1.000$

PCM $1 \mathrm{~km}$
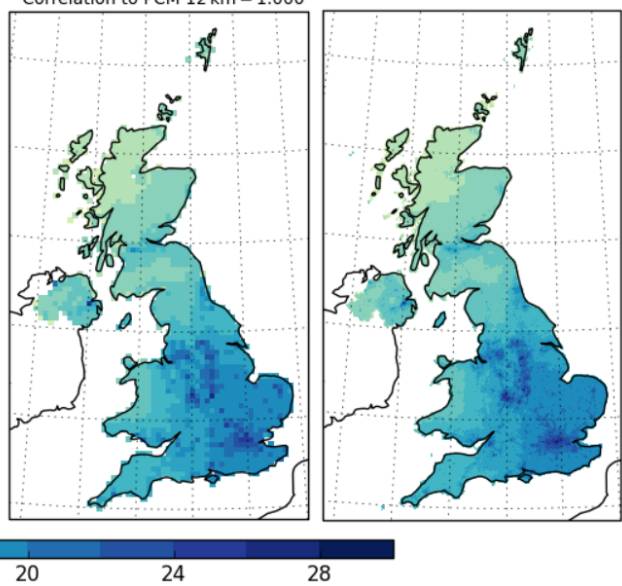

PM10 [ug $\mathrm{m}^{-3}$ ]

Figure 6. Model and PCM mean fields for different pollutants, regridded onto a $12 \mathrm{~km} \mathrm{AQUM} \mathrm{grid.} \mathrm{From} \mathrm{left} \mathrm{to} \mathrm{right} \mathrm{the} \mathrm{models} \mathrm{are} \mathrm{RCCM,}$ AQUM, AQUM-h, a $12 \mathrm{~km}$ version of the PCM, and finally the $1 \mathrm{~km}$ PCM for comparison. Plots also show the correlation between the fields and the $12 \mathrm{~km}$ version of the PCM. Pollutants shown are (a) $\mathrm{NO}_{2}$ (top row), (b) $\mathrm{SO}_{2}$ (middle), and (c) $\mathrm{PM}_{10}$ (bottom). 

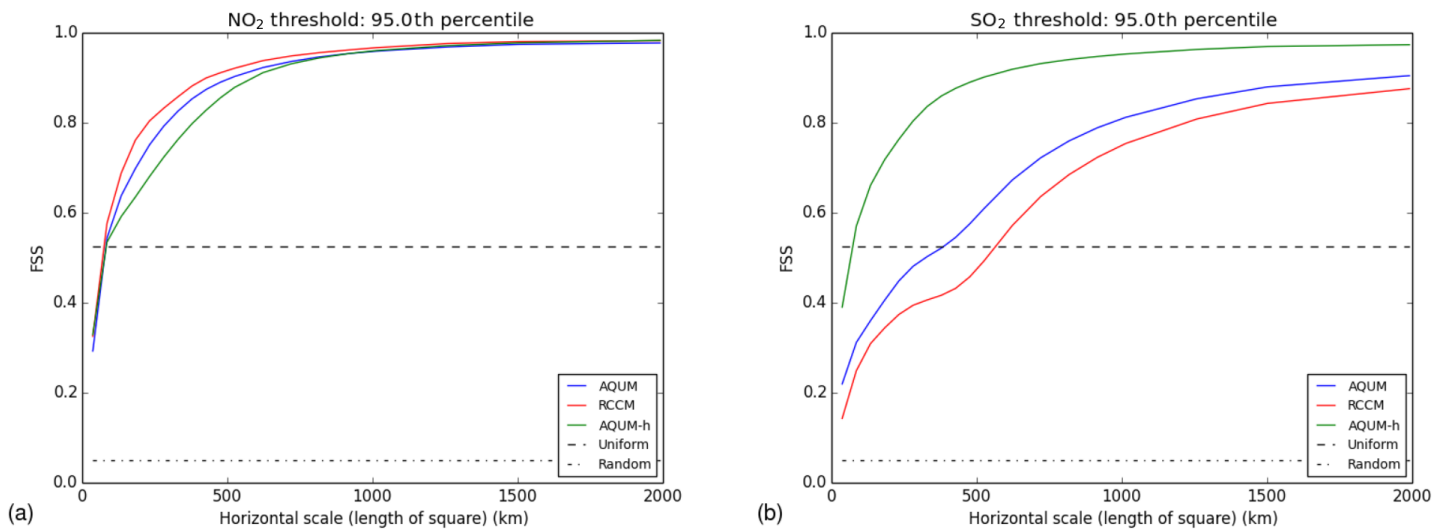

Figure 7. Fractional skill score for the 95 th percentile for (a) $\mathrm{NO}_{2}$ and (b) $\mathrm{SO}_{2}$. The RCCM is shown in red, AQUM in blue, and AQUM-h in green. The "Random" (dot-dashed) line represents the FSS for a random forecast with the same fraction of points over the domain exceeding the percentile threshold as the truth field. The "Uniform" (dashed) line represents a forecast with the same fraction of points above the percentile threshold in the neighbourhood surrounding each grid point as the truth field for every grid point. Above this line the forecast is considered skilful.

the strongly inhomogeneous spatial distribution of these pollutants.

For $\mathrm{PM}_{10}$, however (Fig. 6c), this improvement in correlation with higher resolution is not as clear. The correlation values with the PCM are 0.841 for the RCCM, 0.912 for AQUM, and 0.883 for AQUM-h. $\mathrm{PM}_{10}$ has a large secondary contribution which contributes a relatively smoothly varying background to the PCM maps in Fig. 6c. This is likely to be the reason for the lack of a clear improvement in $\mathrm{PM}_{10}$ modelling with the high-resolution AQUM-h model.

Beyond the figures shown above, we also investigated the correlation scores by just considering data above fixed threshold concentration values (plots not shown). However, these results were very variable, depending on the threshold values considered, partly due to the biases (as given in Sect. 4.2).

\subsection{Analyses based on neighbourhood comparisons: the fractional skill score}

In evaluating a comparison of modelled air pollutant concentrations against some gridded representation of true concentrations (such as the PCM fields described above), small offsets in the spatial location of elevated values can give an exaggerated contribution to simple metrics such as bias and root mean square error evaluated at each grid point. This is commonly referred to as the "double penalty" problem. The resulting analysis may then give a misleading indication of the comparison between the two fields. So-called "neighbourhood" verification techniques (Ebert, 2008; Mittermaier, 2014) have been developed to avoid these problems. Here, we consider the use of the fractional skill score (FSS) (explained in detail in Roberts and Lean, 2008) to analyse the variation in model skill in representing spatial patterns. This statistic has mainly been employed in evalu- ating the improvements offered by high-resolution precipitation forecasts, where a "double penalty" problem occurs if rain is forecast in a neighbouring grid box to where it was actually observed (hence an incorrect forecast in both grid boxes). A lower resolution forecast might place the forecast and observed shower in the same grid box, resulting in an apparently improved forecast. Similar issues are found in pollution modelling due to the high degree of inhomogeneity of air pollutant concentrations and evaluation of the FSS may offer improved comparisons.

The FSS is calculated by computing, for each grid box, the fraction of neighbouring grid boxes which exceed a given threshold value (or percentile). This is done both for the gridded model fields that are to be evaluated and a gridded benchmark field representative of the "truth", which in this case is the PCM fields, as described in Sect. 4.3. This can be repeated for varying neighbourhood sizes. As the size of the neighbourhood increases, the fractional skill score should increase towards unity. A forecast may be considered "skilful" at the grid scale where the model has the correct fraction of points above the percentile threshold in the neighbourhood surrounding each grid point as the truth field for every grid point.

We have calculated the FSS using output from the three model configurations (RCCM, AQUM, and AQUM-h) and compared it to the PCM for various threshold values, based on both fixed thresholds and percentile values. An example set of results is shown in Fig. 7. In these plots, the variation of FSS against the spatial scale is shown for the RCCM, AQUM, and AQUM-h, using a 95th percentile threshold. For $\mathrm{NO}_{2}$, there is little difference between the three model configurations, and the same is found for $\mathrm{PM}_{10}$ (not shown). Calculations using other fixed thresholds and different percentile thresholds also show little difference. However, for 
$\mathrm{SO}_{2}$, AQUM-h shows the best performance, crossing the threshold value of 0.5 at the shortest spatial scale, and reflects the strong point sources of $\mathrm{SO}_{2}$ in contrast to $\mathrm{NO}_{2}$ emissions. The use of neighbourhood verification techniques to compare our different nests has therefore not offered any obvious increased insight into the differences between the models and the consequent impacts on improved predictions across the spatial scales. This may be an indication that the resolution differences between the models may not be the key factor in determining performance, particularly for $\mathrm{NO}_{2}$ and $\mathrm{PM}_{10}$.

\section{Summary and conclusions}

This study describes the initial development of a more consistent framework for dynamic downscaling of climate and air quality from a global composition-climate model to the national scale, via a regional composition-climate model and thence to a higher-resolution regional air quality forecast model. In this attempt, some of the difficulties in presenting a clear-cut, quantitative demonstration of the value of higher resolution modelling have been made apparent. All three models use a single modelling framework - the MetUM - but some differences between the models do remain. The most notable of these are the different chemistry mechanisms, photolysis schemes, and the calibration factor that have been used in the GCCM and RCCM compared to AQUM. AQUM has been developed with forecasting air quality over the UK as its primary aim, and performance has been optimized for predicting in situ UK observations on an hourly timescale with a focus on high impact, more extreme events. By contrast, the GCCM and RCCM have been developed to predict global and regional climatologies, giving a faithful representation of seasonal and annual means across the entire globe. These differences have resulted in some of the inconsistencies highlighted in this paper. This has led to a challenge in determining the benefits of a three-level nest for downscaling to the regional scale, but has highlighted important areas for consideration in future work.

The comparison of modelled air pollutant concentrations against in situ UK observations was conducted initially by a traditional site-specific analysis, with standard metrics such as bias. In addition, the impacts of model resolution on pollutant spatial patterns were assessed via comparison to the gridded PCM annual average pollution maps. In order to guard against the susceptibility of the traditional verification methods to the double penalty problem, an analysis was also carried out using a neighbourhood approach, utilizing the fractional skill score (FSS), although the results from this were generally inconclusive.

For $\mathrm{NO}_{2}$, significantly improved modelled concentrations can be quantitatively demonstrated for the higher-resolution models, using higher resolution emissions (biases of -4.76 , -5.47 , and $-0.80 \mu \mathrm{g} \mathrm{m}^{-3}$ for RCCM, AQUM, and AQUM$\mathrm{h}$, respectively). This is readily understood, given the depen- dence of surface concentrations of this primary pollutant on local emissions. For another primary pollutant, $\mathrm{SO}_{2}$, a modest benefit of high-resolution modelling is demonstrated by the small increase in spatial correlation of AQUM-h with the PCM climatology maps (correlations compared to the PCM of $0.664,0.743$, and 0.761 for RCCM, AQUM, and AQUMh). However, the benefit is less pronounced for $\mathrm{SO}_{2}$ than for $\mathrm{NO}_{2}$. The main reason for this is likely to be that in the UK, $\mathrm{SO}_{2}$ levels have fallen dramatically over the last 25 years and ambient concentrations are now generally the result of relatively low magnitude traffic emissions and much stronger emissions from a small number of industrial point sources. This results in an annually averaged mean concentration map over the UK which shows relatively little spatial structure, but with a small number of locations having much higher concentrations due to strong local emission sources (see the PCM $1 \mathrm{~km}$ plot in Fig. 6b). This low level background with little overall spatial structure limits the quantitative increases in spatial correlation with the PCM climatologies. Another reason may be the impact of the introduction and removal of strong point emissions sources affecting the comparison, as noted in Sect. 4.3.

Conclusions regarding the benefits of high-resolution modelling for $\mathrm{PM}_{2.5}$ have been hampered in the present study due to the lack of observations over the study period. This pollutant has both primary and secondary contributions and one might expect improvements in the modelling of the primary component by higher-resolution modelling. However, the magnitude of the improvement will depend on the relative sizes of primary and secondary components and it may well be that the contribution of the large secondary component masks any improvement in the representation of the primary component. For $\mathrm{PM}_{10}$, model performance remains poor regardless of model resolution, with all three regional models (RCCM, AQUM, and AQUM-h) failing to capture the observed frequency distribution and having negative biases in the range -14.41 to $-12.45 \mu \mathrm{g} \mathrm{m}^{-3}$. Based on the observed PM values analysed by Putaud et al. (2010), it is estimated that the lack of sea salt lowers the modelled $\mathrm{PM}_{10}$ annual mean values by around $12 \%$. Additional important factors in the underprediction of $\mathrm{PM}_{10}$ magnitudes include the absence of coarse component sodium nitrate aerosol, the poor representation of other coarse component primary emissions, and poor modelling of the growth of aerosols to sizes in the coarse range.

For $\mathrm{O}_{3}$, all regional models were able to reproduce the shape of the observation distribution well, but the offset of the modelled from the observed central location varied. Tests showed that the differences are likely to be largely due to differences in the photolysis schemes employed. However, given the modest benefits of higher-resolution modelling found for the other secondary pollutants, it seems unlikely that high-resolution modelling with AQUM would offer significantly improved performance for $\mathrm{O}_{3}$ predictions beyond those demonstrated by the RCCM. 
The model simulations described in this paper have been evaluated in their air quality performance under present-day climate. However, the same techniques can be applied for projecting future climate and air quality from the global scale to the UK national scale (Folberth et al., 2017a). The ability to model air quality at the regional scale will be particularly important for health impact modelling where high spatial resolution is important to allow the concentration variations to be matched to population locations. Indeed, the techniques in this paper have already been applied to 2050s climate and air quality in Pannullo et al. (2017) for assessing potential changes in UK hospital admissions.
Code availability. Due to intellectual property right restrictions, we cannot provide either the source code or documentation papers for the Met Office's Unified Model, MetUM. The MetUM is available for use under licence. A number of research organizations and national meteorological services use the MetUM in collaboration with the Met Office to undertake basic atmospheric process research, produce forecasts, develop the MetUM code, and build and evaluate Earth system models. For further information on how to apply for a licence, see http://www.metoffice.gov.uk/ research/modelling-systems/unified-model. JULES is available under licence free of charge. For further information on how to gain permission to use JULES for research purposes, see http://jules. jchmr.org/content/getting-started. 


\section{Appendix A}

In Table A1 a summary of the parametrization schemes using the three model configurations is presented. Summaries of emission totals are given in Tables A2, A3, and A4.

Table A1. Summary of model configuration settings used in the GCCM, RCCM, and AQUM models.

\begin{tabular}{|c|c|c|c|}
\hline Component & GCCM & $\mathrm{RCCM}$ & AQUM \\
\hline \multicolumn{4}{|l|}{ Model grid } \\
\hline Horizontal resolution (degrees) & $1.875 \times 1.25$ & $0.44 \times 0.44$ & $0.11 \times 0.11$ \\
\hline Vertical levels (and top height, $\mathrm{km}$ ) & $63(41)$ & $63(41)$ & $38(39)$ \\
\hline Dynamical core & \multicolumn{3}{|c|}{$\begin{array}{l}\text { Non-hydrostatic, fully compressible deep atmospheric formulation with semi-Lagrangian advection of prognostic variables (Davies et al., } \\
2005 \text { ) }\end{array}$} \\
\hline Dynamical solver & Generalized conjugate residual (GCR) & GCR + (recommended solver) & GCR+ \\
\hline Dynamical time step (min) & 20 & 12 & 5 \\
\hline Advection & Semi-Lagrangian, monotonic for moisture, tracers & \multicolumn{2}{|c|}{ Semi-Lagrangian, monotonic for theta, moisture and tracers } \\
\hline Conservation & Moisture and tracers & No & No \\
\hline Boundary layer & \multicolumn{2}{|c|}{ Lock et al. (2000) and Lock (2001) with scalar flux-gradient option } & $\begin{array}{l}\text { Lock et al. (2000) and Lock (2001) compati- } \\
\text { ble with JULES }\end{array}$ \\
\hline Convection & \multicolumn{3}{|c|}{ Gregory and Rowntree (1990); Gregory and Allen (1991) mass flux scheme with down-draughts and convective momentum transport (CMT) } \\
\hline CAPE closure & Vertical velocity dependent & Vertical velocity dependent & Vertical velocity dependent \\
\hline Cloud scheme & \multicolumn{2}{|c|}{ Prognostic Cloud and Prognostic Condensate (PC2) } & $\begin{array}{l}\text { Diagnostic cloud and condensate (Smith, } \\
\text { 1990) }\end{array}$ \\
\hline Microphysics (large-scale precip) & \multicolumn{2}{|c|}{ Wilson and Ballard (1999) enhanced for PC2 and graupel } & Wilson and Ballard (1999) \\
\hline Radiation & \multirow{2}{*}{\multicolumn{3}{|c|}{$\begin{array}{l}\text { Edwards and Slingo (1996) with Cusack et al. (1999) for gaseous absorption and incremental adjustments to fluxes and cloud between } \\
\text { full radiation time steps (time stepping). Six SW and nine LW spectral bands } \\
\text { Instantaneous cloud fields, maximum random overlap, water + ice as single mixture, microphysical parametrization for effective radius }\end{array}$}} \\
\hline Cloud representation & & & \\
\hline Land surface & \multicolumn{2}{|c|}{ Met Office Surface Exchange Scheme-II (MOSES) } & Joint UK Land Surface Scheme (JULES) \\
\hline \multirow[t]{2}{*}{ Aerosols } & \multicolumn{3}{|c|}{$\begin{array}{l}\text { CLASSIC Jones et al. (2001), Bellouin et al. (2011) with prognostic treatment of sulfate, dust, soot, fossil fuel organic carbon and nitrate } \\
\text { aerosol. }\end{array}$} \\
\hline & \multicolumn{3}{|c|}{-- Sea salt is diagnostic with emissions derived online using wind speed - - } \\
\hline $\begin{array}{l}\text { Aerosol-radiation and } \\
\text { aerosol-cloud interactions }\end{array}$ & Off & Off & On \\
\hline Chemistry & \multicolumn{2}{|c|}{ Extended Tropospheric Scheme (Folberth et al., 2017b) } & $\begin{array}{l}\text { Regional Air Quality Scheme (Savage et al., } \\
\text { 2013) }\end{array}$ \\
\hline Chemical solver & Explicit Backward Euler & Explicit Backward Euler & Explicit Backward Euler \\
\hline Species (reactions) & $89(203)$ & $89(203)$ & $58(139)$ \\
\hline Aqueous-phase reactions & \multicolumn{3}{|c|}{ - - Includes oxidation of $\mathrm{SO}_{2}$ by both $\mathrm{H}_{2} \mathrm{O}_{2}$ and $\mathrm{O}_{3}$ to form dissolved $\mathrm{SO}_{4}--$} \\
\hline Photolysis scheme & \multicolumn{2}{|c|}{ Offline, 2-Dimensional model with prescribed cloud and aerosol } & Fast-J, uses online cloud and aerosol \\
\hline
\end{tabular}

Table A2. Summary of the annual total emissions of trace gases used in the GCCM, RCCM, and AQUM models. Bold type shows the annual total for each species.

\begin{tabular}{|c|c|c|c|}
\hline Species & GCCM & $\mathrm{RCCM}$ & AQUM \\
\hline $\mathbf{N O} \mathbf{a}_{x} \operatorname{Tg}(\mathbf{N}) \mathbf{y r}^{-1}$ & 49.4 & 8.10 & 2.31 \\
\hline anthropogenic & 26.5 & & \\
\hline forest/grassland fires & 4.3 & & \\
\hline shipping & 5.5 & & \\
\hline soil & 5.6 & & \\
\hline lightning & 7.5 & & \\
\hline $\mathrm{CO}$ as $\mathrm{Tg}(\mathrm{CO}) \mathrm{yr}^{-1}$ & 1112.8 & 83.93 & 20.23 \\
\hline anthropogenic & 607.5 & & \\
\hline forest/grassland fires & 459.1 & & \\
\hline shipping & 1.2 & & \\
\hline oceanic & 45.0 & & \\
\hline $\mathrm{CH}_{4}$ as ppbv* & 1760 & 1760 & 1760 \\
\hline $\mathbf{H}_{2}$ as $\operatorname{Tg}\left(\mathbf{H}_{2}\right) \mathbf{y r}^{-1}$ & 28.9 & 0.61 & 0.055 \\
\hline forest/grassland fires & 28.9 & & \\
\hline
\end{tabular}


Table A3. Summary of the annual total emissions of volatile organic compounds used in the GCCM, RCCM, and AQUM models. Bold type shows the annual total for each species.

\begin{tabular}{|c|c|c|c|c|c|c|c|}
\hline Species & GCCM & RCCM & AQUM & & GCCM & RCCM & AQUM \\
\hline $\mathbf{C}_{2} \mathbf{H}_{6}$ as $\operatorname{Tg}(\mathbf{C}) \mathbf{y r}^{-1}$ & 5.4 & 0.29 & 0.35 & $\mathrm{CH}_{3} \mathrm{CHO}^{\mathrm{b}}$ as $\mathrm{Tg}(\mathrm{C}) \mathrm{yr}^{-1}$ & 4.8 & 0.06 & 0.02 \\
\hline anthropogenic & 2.6 & & & forest/grassland fires & 4.8 & & \\
\hline forest/grassland fires & 2.6 & & & $\mathrm{CH}_{3} \mathrm{C}(\mathrm{O}) \mathrm{CH}_{3}$ & & & \\
\hline shipping & 0.2 & & & as $\operatorname{Tg}(C) y r^{-1}$ & 1.2 & 0.07 & 0.14 \\
\hline $\mathrm{C}_{3} \mathbf{H}_{8}$ as $\mathbf{T g}(\mathbf{C}) \mathbf{y r}^{-1}$ & 4.7 & 0.56 & 0.25 & anthropogenic & 0.2 & & \\
\hline anthropogenic & 2.8 & & & forest/grassland fires & 1.0 & & \\
\hline forest/grassland fires & 1.6 & & & $\mathrm{CH}_{3} \mathrm{C}(\mathrm{O}) \mathrm{CH}_{2} \mathrm{CH}_{3}{ }^{\mathrm{c}}$ & & & \\
\hline shipping & 0.3 & & & as $\mathbf{T g}(\mathbf{C}) \mathbf{y r}^{-1}$ & 2.5 & 0.12 & 0.00 \\
\hline $\mathrm{C}_{4}+$ alkanes as $\operatorname{Tg}(\mathbf{C}) \mathrm{yr}^{-1}$ & 24.7 & 4.55 & 0.55 & anthropogenic & 0.3 & & \\
\hline anthropogenic & 23.3 & & & forest/grassland fires & 2.2 & & \\
\hline forest/grassland fires & 0.6 & & & $\operatorname{aromatics}^{\mathrm{d}}$ as $\mathrm{Tg}(\mathrm{C}) \mathrm{yr}^{-1}$ & 17.8 & 2.13 & 0.30 \\
\hline shipping & 0.8 & & & anthropogenic & 13.8 & & \\
\hline $\mathrm{C}_{2} \mathrm{H}_{4}$ as $\mathrm{Tg}(\mathrm{C}) \mathrm{yr}^{-1}$ & 16.5 & 1.13 & 0.19 & forest/grassland fires & 3.7 & & \\
\hline anthropogenic & 9.4 & & & shipping & 0.3 & & \\
\hline forest/grassland fires & 6.8 & & & & & & \\
\hline shipping & 0.3 & & & BVOC as $\operatorname{Tg}(C) \mathbf{y r}^{-1}$ & 680 & & 0.87 \\
\hline $\mathrm{C}_{3}+$ alkenes $^{\mathrm{a}}$ as $\operatorname{Tg}(\mathrm{C}) \mathrm{yr}^{-1}$ & 6.4 & 0.33 & 0.08 & as isoprene & 480 & & 0.87 \\
\hline anthropogenic & 2.7 & & & as (mono-)terpenes & 95 & & 0 \\
\hline forest/grassland fires & 3.4 & & & as methanol & 85 & & 0 \\
\hline shipping & 0.3 & & & as acetone & 20 & & 0 \\
\hline HCHO as $\mathrm{Tg}(\mathrm{C}) \mathrm{yr}^{-1}$ & 3.6 & 0.25 & 0.06 & & & & \\
\hline anthropogenic & 1.3 & & & & & & \\
\hline forest/grassland fires & 2.3 & & & & & & \\
\hline
\end{tabular}

Table A4. Summary of the annual total emissions of aerosols used in the GCCM, RCCM, and AQUM models. Bold type shows the annual total for each species.

\begin{tabular}{|c|c|c|c|}
\hline Species & GCCM & RCCM & AQUM \\
\hline black carbon $(\mathrm{BC})$ as $\mathrm{Tg}(\mathrm{BC}) \mathrm{yr}^{-1}$ & 6.4 & 0.87 & 0.23 \\
\hline anthropogenic & 6.4 & & \\
\hline shipping & 0.03 & & \\
\hline organic carbon $(\mathrm{OC})$ as $\mathrm{Tg}(\mathrm{OC}) \mathrm{yr}^{-1}$ & 24.3 & 1.84 & 0.23 \\
\hline anthropogenic & 23.6 & & \\
\hline shipping & 0.7 & & \\
\hline $\mathbf{N H}_{3}$ as $\mathbf{T g}(\mathbf{N}) \mathbf{y r}^{-1}$ & 35.4 & 6.98 & 1.67 \\
\hline anthropogenic & 32.8 & & \\
\hline forest/grassland fires & 2.6 & & \\
\hline $\mathrm{SO}_{2}$ as $\mathbf{T g}\left(\mathrm{SO}_{2}\right) \mathrm{yr}^{-1}$ & 107.3 & 22.61 & 1.90 \\
\hline anthropogenic & 87.6 & & \\
\hline forest/grassland fires & 12.2 & & \\
\hline shipping & 7.5 & & \\
\hline
\end{tabular}


Competing interests. The authors declare that they have no conflict of interest.

Acknowledgements. The development of HadGEM3, UKCA, and the work of Mohit Dalvi, Gerd Folberth, and Fiona M. O'Connor were supported by the Joint UK BEIS/Defra Met Office Hadley Centre Climate Programme (GA01101). Lucy S. Nea, Mohit Dalvi, Gerd Folberth, Rachel N. McInnes, and Paul Agnew also acknowledge the Engineering and Physical Sciences Research Council (EPSRC) for additional funding through the UK Engineering and Physical Sciences research council grant number EP/J017485/1: "A rigorous statistical framework for estimating the long-term health effects of air pollution". In addition, this work and its contributors (GF and FMO'C) were partly supported by the UK-China Research \& Innovation Partnership Fund through the Met Office Climate Science for Service Partnership (CSSP) China as part of the Newton Fund.

Edited by: Olaf Morgenstern

Reviewed by: two anonymous referees

\section{References}

Allen, R. J., Landuyt, W., and Rumbold, S. T.: An increase in aerosol burden and radiative effects in a warmer world, Nat. Clim. Chang., 6, 269-274, https://doi.org/10.1038/NCLIMATE2827, 2016.

Arneth, A., Niinemets, Ü., Pressley, S., Bäck, J., Hari, P., Karl, T., Noe, S., Prentice, I. C., Serça, D., Hickler, T., Wolf, A., and Smith, B.: Process-based estimates of terrestrial ecosystem isoprene emissions: incorporating the effects of a direct $\mathrm{CO}_{2}$-isoprene interaction, Atmos. Chem. Phys., 7, 31-53, https://doi.org/10.5194/acp-7-31-2007, 2007.

Arneth, A., Monson, R. K., Schurgers, G., Niinemets, Ü., and Palmer, P. I.: Why are estimates of global terrestrial isoprene emissions so similar (and why is this not so for monoterpenes)?, Atmos. Chem. Phys., 8, 4605-4620, https://doi.org/10.5194/acp8-4605-2008, 2008.

Ashworth, K., Folberth, G., Hewitt, C. N., and Wild, O.: Impacts of near-future cultivation of biofuel feedstocks on atmospheric composition and local air quality, Atmos. Chem. Phys., 12, 919939, https://doi.org/10.5194/acp-12-919-2012, 2012.

Baklanov, A., Schlünzen, K., Suppan, P., Baldasano, J., Brunner, D., Aksoyoglu, S., Carmichael, G., Douros, J., Flemming, J., Forkel, R., Galmarini, S., Gauss, M., Grell, G., Hirtl, M., Joffre, S., Jorba, O., Kaas, E., Kaasik, M., Kallos, G., Kong, X., Korsholm, U., Kurganskiy, A., Kushta, J., Lohmann, U., Mahura, A., Manders-Groot, A., Maurizi, A., Moussiopoulos, N., Rao, S. T., Savage, N., Seigneur, C., Sokhi, R. S., Solazzo, E., Solomos, S., Sørensen, B., Tsegas, G., Vignati, E., Vogel, B., and Zhang, Y.: Online coupled regional meteorology chemistry models in Europe: current status and prospects, Atmos. Chem. Phys., 14, 317-398, https://doi.org/10.5194/acp-14-317-2014, 2014.

Bellouin, N., Rae, J., Jones, A., Johnson, C., Haywood, J., and Boucher, O.: Aerosol forcing in the Climate Model Intercomparison Project (CMIP5) simulations by HadGEM2-ES and the role of ammonium nitrate, J. Geophys. Res.-Atmos., 116, D20206, https://doi.org/10.1029/2011JD016074, 2011.

Best, M. J., Pryor, M., Clark, D. B., Rooney, G. G., Essery, R. L. H., Ménard, C. B., Edwards, J. M., Hendry, M. A., Porson, A., Gedney, N., Mercado, L. M., Sitch, S., Blyth, E., Boucher, O., Cox, P. M., Grimmond, C. S. B., and Harding, R. J.: The Joint UK Land Environment Simulator (JULES), model description Part 1: Energy and water fluxes, Geosci. Model Dev., 4, 677-699, https://doi.org/10.5194/gmd-4-677-2011, 2011.

Boucher, O., Randall, D., Artaxo, P., Bretherton, C., Feingold, G., Forster, P., Kerminen, V.-M., Kondo, Y., Liao, H., Lohmann, U., Rasch, P., Satheesh, S., Sherwood, S., Stevens, B., and Zhang, X.: Clouds and Aerosols, book section 7, 571-658, Cambridge University Press, Cambridge, UK and New York, NY, USA, https://doi.org/10.1017/CBO9781107415324.016, 2013.

Brookes, M. D., Stedman, J. R., Kent, A. J., Morris, R. J., Cooke, S. L., Lingard, J. J. N., Rose, R. A., Vincent, K. J., Bush, T. J., and Abbott, J.: Technical report on UK supplementary assessment under the Air Quality Directive(2008/50/EC), the Air Quality Framework Directive(96/62/EC) and Fourth Daughter Directive(2004/107/EC) for 2012, Tech. rep., The Department for Environment, Food and Rural Affairs, Welsh Government, the Scottish Government and the Department of the Environment for Northern Ireland, available at: http://uk-air.defra.gov.uk/assets/documents/reports/cat09/ 1312231525_AQD_DD4_2012mapsrepv0.pdf (last access: 23 October 2017), 2013.

Brown, A., Milton, S., Cullen, M., Golding, B., Mitchell, J., and Shelly, A.: Unified Modeling And Prediction Of Weather And Climate A 25-Year Journey, B. Am. Meteorol. Soc., 93, 18651877, 2012.

Chemel, C., Fisher, B., Kong, X., Francis, X., Sokhi, R., Good, N., Collins, W., and Folberth, G.: Application of chemical transport model CMAQ to policy decisions regarding $\mathrm{PM}_{2.5}$ in the UK, Atmos. Environ., 82, 410-417, https://doi.org/10.1016/j.atmosenv.2013.10.001, 2014.

Colette, A., Granier, C., Hodnebrog, Ø., Jakobs, H., Maurizi, A., Nyiri, A., Bessagnet, B., D’Angiola, A., D'Isidoro, M., Gauss, M., Meleux, F., Memmesheimer, M., Mieville, A., Rouïl, L., Russo, F., Solberg, S., Stordal, F., and Tampieri, F.: Air quality trends in Europe over the past decade: a first multimodel assessment, Atmos. Chem. Phys., 11, 11657-11678, https://doi.org/10.5194/acp-11-11657-2011, 2011.

Collins, W. J., Bellouin, N., Doutriaux-Boucher, M., Gedney, N., Halloran, P., Hinton, T., Hughes, J., Jones, C. D., Joshi, M., Liddicoat, S., Martin, G., O’Connor, F., Rae, J., Senior, C., Sitch, S., Totterdell, I., Wiltshire, A., and Woodward, S.: Development and evaluation of an Earth-System model - HadGEM2, Geosci. Model Dev., 4, 1051-1075, https://doi.org/10.5194/gmd-4-10512011, 2011.

COMEAP: Quantification of mortality and hospital admissions associated with ground-level ozone, Committee on the Medical Effects of Air Pollutants, UK, available at: https://www.gov. uk/government/collections/comeap-reports (last access: 23 October 2017), 2015.

Cusack, S., Edwards, J. M., and Crowther, J. M.: Investigating k distribution methods for parameterizing gaseous absorption in the Hadley Centre Climate Model, J. Geophys. Res.-Atmos., 104, 2051-2057, https://doi.org/10.1029/1998JD200063, 1999. 
Davies, T., Cullen, M. J. P., Malcolm, A. J., Mawson, M. H., Staniforth, A., White, A. A., and Wood, N.: A new dynamical core for the Met Office's global and regional modelling of the atmosphere, Q. J. Roy. Meteor. Soc., 131, 1759-1782, https://doi.org/10.1256/qj.04.101, 2005.

Dore, C. J., Murrells, T. P., Passant, N. R., Hobson, M. M., Thistlethwaite, G., Wagner, A., Li, Y., Bush, T., King, K. R., Norris, J., Coleman, P. J., Walker, C., Stewart, R. A., Tsagatakis, I., Conolly, C., Brophy, N. C. J., and Hann, M. R.: UK Emissions of Air Pollutants 1970 to 2006, Tech. rep., AEA, available at: http://uk-air.defra.gov.uk/reports/cat07/ 0810291043_NAEI_2006_Report_Final_Version(3).pdf (last access: 23 October 2017), 2008.

Ebert, E. E.: Fuzzy verification of high-resolution gridded forecasts: a review and proposed framework, Meteorol. Appl., 15, 51-64, https://doi.org/10.1002/met.25, 2008.

Edwards, J. M. and Slingo, A.: Studies with a flexible new radiation code. I: Choosing a configuration for a largescale model, Q. J. Roy. Meteor. Soc., 122, 689-719, https://doi.org/10.1002/qj.49712253107, 1996.

Eyring, V., Arblaster, J. M., Cionni, I., Sedlacek, J., Perliwitz, J., Young, P. J., Bekki, S., Bergmann, D., Cameron-Smith, P., Collins, W. J., Faluvegi, G., Gottschaldt, K. D., Horowitz, L. W., Kinnison, D. E., Lamarque, J. F., Marsh, D. R., Saint-Martin, D., Shindell, D. T., Sudo, K., Szopa, S., and Watanabe, S.: Long-term ozone changes and associated climate impacts in CMIP5 simulations, J. Geophys. Res.-Atmos., 118, 5029-5060, https://doi.org/10.1002/jgrd.50316, 2013.

Fiore, A. M., Naik, V., Spracklen, D. V., Steiner, A., Unger, N., Prather, M., Bergmann, D., Cameron-Smith, P. J., Cionni, I., Collins, W. J., Dalsoren, S., Eyring, V., Folberth, G. A., Ginoux, P., Horowitz, L. W., Josse, B., Lamarque, J.-F., MacKenzie, I. A., Nagashima, T., O'Connor, F. M., Righi, M., Rumbold, S. T., Shindell, D. T., Skeie, R. B., Sudo, K., Szopa, S., Takemura, T., and Zeng, G.: Global air quality and climate, Chem. Soc. Rev., 41, 6663-6683, https://doi.org/10.1039/c2cs35095e, 2012.

Folberth, G., McInnes, R. N., Dalvi, M., Neal, L. S., Agnew, P., Clewlow, Y., Hemming, D., O'Connor, F., and Sarran, C.: Future projections of UK air quality and potential implications for health, in preparation, 2017a.

Folberth, G. A., Abraham, N. L., Johnson, C. E., Morgenstern, O., O'Connor, F. M., Pacifico, F., Young, P. A., Collins, W. J., and Pyle, J. A.: Evaluation of the new UKCA climate-composition model. Part III. Extension to tropospheric chemistry and biogeochemical coupling between atmosphere and biosphere, in preparation, $2017 \mathrm{~b}$.

Forkel, R. and Knoche, R.: Regional climate change and its impact on photooxidant concentrations in southern Germany: Simulations with a coupled regional climatechemistry model, J. Geophys. Res.-Atmos., 111, D12302, https://doi.org/10.1029/2005JD006748, 2006.

Gregory, D. and Allen, S.: The effect of convective downdraughts upon NWP and climate simulations, 122-123, Nineth conference on numerical weather prediction, Denver, Colorado, 1991.

Gregory, D. and Rowntree, P. R.: A mass flux convection scheme with representation of cloud ensemble characteristics and stability-dependent closure, Mon. Weather Rev., 118, 1483-1506, https://doi.org/10.1175/15200493(1990)118<1483:AMFCSW>2.0.CO;2, 1990.
Grell, G., Peckham, S., Schmitz, R., McKeen, S., Frost, G., Skamarock, W., and Eder, B.: Fully coupled "online" chemistry within the WRF model, Atmos. Environ., 39, 6957-6975, https://doi.org/10.1016/j.atmosenv.2005.04.027, 2005.

Guenther, A., Hewitt, C. N., Erickson, D., Fall, R., Geron, C., Graedel, T., Harley, P., Klinger, L., Lerdau, M., Mckay, W. A., Pierce, T., Scholes, B., Steinbrecher, R., Tallamraju, R., Taylor, J., and Zimmermann, P.: A global model of natural volatile organic compound emissions, J. Geophys. Res., 100, 8873-8892, 1995.

Guenther, A., Karl, T., Harley, P., Wiedinmyer, C., Palmer, P. I., and Geron, C.: Estimates of global terrestrial isoprene emissions using MEGAN (Model of Emissions of Gases and Aerosols from Nature), Atmos. Chem. Phys., 6, 3181-3210, https://doi.org/10.5194/acp-6-3181-2006, 2006.

He, J., Zhang, Y., Glotfelty, T., He, R., Bennartz, R., Rausch, J., and Sartelet, K.: Decadal simulation and comprehensive evaluation of CESM/CAM5.1 with advanced chemistry, aerosol microphysics, and aerosol-cloud interactions, J. Adv. Model. Earth Sy., 7, 110-141, https://doi.org/10.1002/2014MS000360, 2015.

Heal, M. R., Heaviside, C., Doherty, R. M., Vieno, M., Stevenson, D. S., and Vardoulakis, S.: Health burdens of surface ozone in the UK for a range of future scenarios, Environ. Int., 61, 36-44, https://doi.org/10.1016/j.envint.2013.09.010, 2013.

Hoerling, M. P., Schaack, T. K., and Lenzen, A. J.: A Global Analysis of Stratospheric-Tropospheric Exchange during Northern Winter, Mon. Weather Rev., 121, 162-172, https://doi.org/10.1175/15200493(1993)121<0162:AGAOSE>2.0.CO;2, 1993.

Hong, C., Zhang, Q., Zhang, Y., Tang, Y., Tong, D., and He, K.: Multi-year downscaling application of two-way coupled WRF v3.4 and CMAQ v5.0.2 over east Asia for regional climate and air quality modeling: model evaluation and aerosol direct effects, Geosci. Model Dev., 10, 2447-2470, https://doi.org/10.5194/gmd-10-2447-2017, 2017.

Hough, A.: The calculation of photolysis rates for use in global tropospheric modelling studies, Tech. Rep. 13259, Atomic Energy Research Establishment, Harvel, UK, 1988.

Hurrell, J. W., Holland, M. M., Gent, P. R., Ghan, S., Kay, J. E., Kushner, P. J., Lamarque, J.-F., Large, W. G., Lawrence, D., Lindsay, K., Lipscomb, W. H., Long, M. C., Mahowald, N., Marsh, D. R., Neale, R. B., Rasch, P., Vavrus, S., Vertenstein, M., Bader, D., Collins, W. D., Hack, J. J., Kiehl, J., and Marshall, S.: The Community Earth System Model: a framework for collaborative research, B. Am. Meteorol. Soc., 94, 1339-1360, https://doi.org/10.1175/BAMS-D-12-00121.1, 2013.

Hurtt, G. C., Chini, L. P., Frolking, S., Betts, R. A., Feddema, J., Fischer, G., Fisk, J. P., Hibbard, K., Houghton, R. A., Janetos, A., Jones, C. D., Kindermann, G., Kinoshita, T., Goldewijk, K. K., Riahi, K., Shevliakova, E., Smith, S., Stehfest, E., Thomson, A., Thornton, P., van Vuuren, D. P., and Wang, Y. P.: Harmonization of land-use scenarios for the period 1500-2100: 600 years of global gridded annual land-use transitions, wood harvest, and resulting secondary lands, Climatic Change, 109, 117-161, 2011. Im, U., Bianconi, R., Solazzo, E., Kioutsioukis, I., Badia, A. A. B., Baro, R., Bellasio, R., Brunner, D., Chemel, C., Curci, G., Denier van der Gon, H., Flemming, J., Forkel, R., Giordano, L., Jimenez-Guerrero, P., Hirtl, M., Hodzic, A., Honzak, L., Jorba, O., Knote, C., Makar, P. A., Manders-Groot, A., 
Neal, L., Perez, J. L., Pirovano, G., Pouliot, G. R. S. J., Savage, N., Schroder, W., Sokhi, R. S., Syrakov, D., Torian, A., Tuccella, P., Wang, K., Werhahn, J., Wolke, R., Zabkar, R., Zhang, Y., Zhang, J., Hogrefe, C., and Galmarini, S.: Evaluation of operational online-coupled regional air quality models over Europe and North America in the context of AQMEII phase 2. Part II: Particulate matter, Atmos. Environ., 115, 421-441, https://doi.org/10.1016/j.atmosenv.2014.08.072, 2015.

Jacob, D. J. and Winner, D. A.: Effect of climate change on air quality, Atmos. Environ., 43, 51-63, https://doi.org/10.1016/j.atmosenv.2008.09.051, 2009.

Jacobson, M. Z.: GATOR-GCMM: A global-through urban-scale air pollution and weather forecast model: 1 . Model design and treatment of subgrid soil, vegetation, roads, rooftops, water, sea ice, and snow, J. Geophys. Res.-Atmos., 106, 5385-5401, https://doi.org/10.1029/2000JD900560, 2001.

Jones, A., Roberts, D. L., Woodage, M. J., and Johnson, C. E.: Indirect sulphate aerosol forcing in a climate model with an interactive sulphur cycle, J. Geophys. Res., 106, 20293-20310, 2001.

Jones, C. D., Hughes, J. K., Bellouin, N., Hardiman, S. C., Jones, G. S., Knight, J., Liddicoat, S., O’Connor, F. M., Andres, R. J., Bell, C., Boo, K.-O., Bozzo, A., Butchart, N., Cadule, P., Corbin, K. D., Doutriaux-Boucher, M., Friedlingstein, P., Gornall, J., Gray, L., Halloran, P. R., Hurtt, G., Ingram, W. J., Lamarque, J.-F., Law, R. M., Meinshausen, M., Osprey, S., Palin, E. J., Parsons Chini, L., Raddatz, T., Sanderson, M. G., Sellar, A. A., Schurer, A., Valdes, P., Wood, N., Woodward, S., Yoshioka, M., and Zerroukat, M.: The HadGEM2-ES implementation of CMIP5 centennial simulations, Geosci. Model Dev., 4, 543-570, https://doi.org/10.5194/gmd-4-543-2011, 2011.

Kettle, A. J., Andreae, M. O., Amouroux, D., Andreae, T. W., Bates, T. S., Berresheim, H., Bingemer, H., Boniforti, R., Curran, M. A. J., DiTullio, G. R., Helas, G., Jones, G. B., Keller, M. D., Kiene, R. P., Leck, C., Levasseur, M., Malin, G., Maspero, M., Matrai, P., McTaggart, A. R., Mihalopoulos, N., Nguyen, B. C., Novo, A., Putaud, J. P., Rapsomanikis, S., Roberts, G., Schebeske, G., Sharma, S., Simó, R., Staubes, R., Turner, S., and Uher, G.: A global database of sea surface dimethylsulfide (DMS) measurements and a procedure to predict sea surface DMS as a function of latitude, longitude, and month, Global Biogeochem. Cy., 13, 399-444, https://doi.org/10.1029/1999GB900004, 1999.

Kunkel, K., Huang, H.-C., Liang, X.-Z., Lin, J.-T., Wuebbles, D., Tao, Z., Williams, A., Caughey, M., Zhu, J., and Hayhoe, K.: Sensitivity of future ozone concentrations in the northeast USA to regional climate change, Mitigation Adapt. Strateg. Glob. Chang., 13, 597-606, https://doi.org/10.1007/s11027-007-9137y, 2008.

Lamarque, J.-F., Bond, T. C., Eyring, V., Granier, C., Heil, A., Klimont, Z., Lee, D., Liousse, C., Mieville, A., Owen, B., Schultz, M. G., Shindell, D., Smith, S. J., Stehfest, E., Van Aardenne, J., Cooper, O. R., Kainuma, M., Mahowald, N., McConnell, J. R., Naik, V., Riahi, K., and van Vuuren, D. P.: Historical (1850-2000) gridded anthropogenic and biomass burning emissions of reactive gases and aerosols: methodology and application, Atmos. Chem. Phys., 10, 7017-7039, https://doi.org/10.5194/acp-10-7017-2010, 2010.

Lamarque, J.-F., Shindell, D. T., Josse, B., Young, P. J., Cionni, I., Eyring, V., Bergmann, D., Cameron-Smith, P., Collins, W. J., Do- herty, R., Dalsoren, S., Faluvegi, G., Folberth, G., Ghan, S. J., Horowitz, L. W., Lee, Y. H., MacKenzie, I. A., Nagashima, T., Naik, V., Plummer, D., Righi, M., Rumbold, S. T., Schulz, M., Skeie, R. B., Stevenson, D. S., Strode, S., Sudo, K., Szopa, S., Voulgarakis, A., and Zeng, G.: The Atmospheric Chemistry and Climate Model Intercomparison Project (ACCMIP): overview and description of models, simulations and climate diagnostics, Geosci. Model Dev., 6, 179-206, https://doi.org/10.5194/gmd-6179-2013, 2013.

Langner, J., Engardt, M., Baklanov, A., Christensen, J. H., Gauss, M., Geels, C., Hedegaard, G. B., Nuterman, R., Simpson, D., Soares, J., Sofiev, M., Wind, P., and Zakey, A.: A multi-model study of impacts of climate change on surface ozone in Europe, Atmos. Chem. Phys., 12, 10423-10440, https://doi.org/10.5194/acp-12-10423-2012, 2012.

Lathière, J., Hauglustaine, D. A., De Noblet-Ducoudré, N., Krinner, G., and Folberth, G. A.: Past and future changes in biogenic volatile organic compound emissions simulated with a global dynamic vegetation model, Geophys. Res. Lett., 32, L20818, https://doi.org/10.1029/2005GL024164, 2005.

Lauwaet, D., Viaene, P., Brisson, E., van Noije, T., Strunk, A., Looy, S. V., Maiheu, B., Veldeman, N., Blyth, L., Ridder, K. D., and Janssen, S.: Impact of nesting resolution jump on dynamical downscaling ozone concentrations over Belgium, Atmos. Environ., 67, 46-52, https://doi.org/10.1016/j.atmosenv.2012.10.034, 2013.

Law, K. and Pyle, J.: Modeling trace gas budgets in the troposphere. 1 - ozone and odd nitrogen, J. Geophys. Res., 98, 18377-18400, 1993.

Likhvar, V. N., Pascal, M., Markakis, K., Colette, A., Hauglustaine, D., Valari, M., Klimont, Z., Medina, S., and Kinney, P.: A multi-scale health impact assessment of air pollution over the 21st century, Sci. Total Environ., 514, 439-449, https://doi.org/10.1016/j.scitotenv.2015.02.002, 2015.

Lock, A., Brown, A., Bush, M., Martin, G., and Smith, R.: A new boundary layer mixing scheme. Part I: Scheme description and single-column model tests, Mon. Weather Rev., 128, 3187-3199, 2000.

Lock, A. P.: The numerical representation of entrainment in parameterizations of boundary layer turbulent mixing, Mon. Weather Rev., 129, 1148-1163, https://doi.org/10.1175/15200493(2001)129<1148:TNROEI>2.0.CO;2, 2001.

Mann, G. W., Carslaw, K. S., Spracklen, D. V., Ridley, D. A., Manktelow, P. T., Chipperfield, M. P., Pickering, S. J., and Johnson, C. E.: Description and evaluation of GLOMAP-mode: a modal global aerosol microphysics model for the UKCA composition-climate model, Geosci. Model Dev., 3, 519-551, https://doi.org/10.5194/gmd-3-519-2010, 2010.

Meleux, F., Solmon, F., and Giorgi, F.: Increase in summer European ozone amounts due to climate change, Atmos. Environ., 41, 7577-7587, https://doi.org/10.1016/j.atmosenv.2007.05.048, 2007.

Mercado, L. M., Bellouin, N., Sitch, S., Boucher, O., Huntingford, C., Wild, M., and Cox, P. M.: Impact of changes in diffuse radiation on the global land carbon sink, Nature, 458, 1014-1017, https://doi.org/10.1038/nature07949, 2009.

Messina, P., Lathière, J., Sindelarova, K., Vuichard, N., Granier, C., Ghattas, J., Cozic, A., and Hauglustaine, D. A.: Global biogenic volatile organic compound emissions in the ORCHIDEE 
and MEGAN models and sensitivity to key parameters, Atmos. Chem. Phys., 16, 14169-14202, https://doi.org/10.5194/acp-1614169-2016, 2016.

Mittermaier, M. P.: A strategy for verifying near-convectionresolving model forecasts at observing sites, Weather Forecast., 29, 185-204, https://doi.org/10.1175/WAF-D-12-00075.1, 2014.

Morgenstern, O., Braesicke, P., O’Connor, F. M., Bushell, A. C., Johnson, C. E., Osprey, S. M., and Pyle, J. A.: Evaluation of the new UKCA climate-composition model Part 1: The stratosphere, Geosci. Model Dev., 2, 43-57, https://doi.org/10.5194/gmd-2-43-2009, 2009.

Moufouma-Okia, W. and Jones, R.: Resolution dependence in simulating the African hydroclimate with the HadGEM3RA regional climate model, Clim. Dynam., 44, 609-632, https://doi.org/10.1007/s00382-014-2322-2, 2015.

Müller, J.-F., Stavrakou, T., Wallens, S., De Smedt, I., Van Roozendael, M., Potosnak, M. J., Rinne, J., Munger, B., Goldstein, A., and Guenther, A. B.: Global isoprene emissions estimated using MEGAN, ECMWF analyses and a detailed canopy environment model, Atmos. Chem. Phys., 8, 1329-1341, https://doi.org/10.5194/acp-8-1329-2008, 2008.

Murphy, D. M. and Fahey, D. W.: An estimate of the flux of stratospheric reactive nitrogen and ozone into the troposphere, J. Geophys. Res.-Atmos., 99, 5325-5332, https://doi.org/10.1029/93JD03558, 1994.

Myhre, G., Shindell, D., Breon, F.-M., Collins, W., Fuglestvedt, J., Huang, J., Koch, D., Lamarque, J.-F., Lee, D., Mendoza, B., Nakajima, T., Robock, A., Stephens, G., Takemura, T., and Zhang, H.: Anthropogenic and Natural Radiative Forcing, book section 8, 659-740, Cambridge University Press, Cambridge, UK and New York, NY, USA, https://doi.org/10.1017/CBO9781107415324.018, 2013.

O’Connor, F. M., Johnson, C. E., Morgenstern, O., Abraham, N. L., Braesicke, P., Dalvi, M., Folberth, G. A., Sanderson, M. G., Telford, P. J., Voulgarakis, A., Young, P. J., Zeng, G., Collins, W. J., and Pyle, J. A.: Evaluation of the new UKCA climatecomposition model - Part 2: The Troposphere, Geosci. Model Dev., 7, 41-91, https://doi.org/10.5194/gmd-7-41-2014, 2014.

Pacifico, F., Harrison, S. P., Jones, C. D., Arneth, A., Sitch, S., Weedon, G. P., Barkley, M. P., Palmer, P. I., Serça, D., Potosnak, M., Fu, T.-M., Goldstein, A., Bai, J., and Schurgers, G.: Evaluation of a photosynthesis-based biogenic isoprene emission scheme in JULES and simulation of isoprene emissions under presentday climate conditions, Atmos. Chem. Phys., 11, 4371-4389, https://doi.org/10.5194/acp-11-4371-2011, 2011.

Pacifico, F., Folberth, G. A., Sitch, S., Haywood, J. M., Rizzo, L. V., Malavelle, F. F., and Artaxo, P.: Biomass burning related ozone damage on vegetation over the Amazon forest: a model sensitivity study, Atmos. Chem. Phys., 15, 2791-2804, https://doi.org/10.5194/acp-15-2791-2015, 2015.

Pannullo, F., Lee, D., Neal, L., Dalvi, M., Agnew, P., O’Connor, F. M., Mukhopadhyay, S., Sahu, S., and Sarran, C.: Quantifying the impact of current and future air pollution concentrations on respiratory disease risk in England, Environ. Health, 16, 29, https://doi.org/10.1186/s12940-017-0237-1, 2017.

Price, C. and Rind, D.: A simple lightning parameterization for calculating global lightning distributions, J. Geophys. Res., 97, 9919-9933, 1992.
Price, C. and Rind, D.: What determines the cloud-to-ground lightning fraction in thunderstorms, Geophys. Res. Lett., 20, 463466, 1993.

Price, C. and Rind, D.: Modeling global lightning distributions in a general circulation model, Mon. Weather Rev., 122, 1930-1939, 1994.

Price, C., Penner, J., and Prather, M.: $\mathrm{NO}_{x}$ from lightning. 2. Constraints from the global atmospheric electric circuit, J. Geophys. Res., 102, 5943-5951, https://doi.org/10.1029/96JD02551, 1997.

Putaud, J.-P., Dingenen, R. V., Alastuey, A., Bauer, H., Birmili, W., Cyrys, J., Flentje, H., Fuzzi, S., Gehrig, R., Hansson, H., Harrison, R., Herrmann, H., Hitzenberger, R., Hüglin, C., Jones, A., Kasper-Giebl, A., Kiss, G., Kousa, A., Kuhlbusch, T., Löschau, G., Maenhaut, W., Molnar, A., Moreno, T., Pekkanen, J., Perrino, C., Pitz, M., Puxbaum, H., Querol, X., Rodriguez, S., Salma, I., Schwarz, J., Smolik, J., Schneider, J., Spindler, G., ten Brink, H., Tursic, J., Viana, M., Wiedensohler, A., and Raes, F.: A European aerosol phenomenology - 3: Physical and chemical characteristics of particulate matter from 60 rural, urban, and kerbside sites across Europe, Atmos. Environ., 44, 1308-1320, https://doi.org/10.1016/j.atmosenv.2009.12.011, 2010.

Riahi, K., Grübler, A., and Nakicenovic, N.: Scenarios of longterm socio-economic and environmental development under climate stabilization, Technol. Forecast. Soc., 74, 887-935, https://doi.org/10.1016/j.techfore.2006.05.026, 2007.

Roberts, N. M. and Lean, H. W.: Scale-selective verification of rainfall accumulations from high-resolution forecasts of convective events, Mon. Weather Rev., 136, 78-97, https://doi.org/10.1175/2007MWR2123.1, 2008.

Sanderson, M. G., Jones, C. D., Collins, W. J., Johnson, C. E., and Derwent, R. G.: Effect of climate change on isoprene emissions and surface ozone levels, Geophys. Res. Lett., 30, 1936 , https://doi.org/10.1029/2003GL017642, 2003.

Savage, N. H., Agnew, P., Davis, L. S., Ordóñez, C., Thorpe, R., Johnson, C. E., O'Connor, F. M., and Dalvi, M.: Air quality modelling using the Met Office Unified Model (AQUM OS24-26): model description and initial evaluation, Geosci. Model Dev., 6, 353-372, https://doi.org/10.5194/gmd-6-353-2013, 2013.

Schumann, U. and Huntrieser, H.: The global lightning-induced nitrogen oxides source, Atmos. Chem. Phys., 7, 3823-3907, https://doi.org/10.5194/acp-7-3823-2007, 2007.

Shalaby, A., Zakey, A. S., Tawfik, A. B., Solmon, F., Giorgi, F., Stordal, F., Sillman, S., Zaveri, R. A., and Steiner, A. L.: Implementation and evaluation of online gas-phase chemistry within a regional climate model (RegCM-CHEM4), Geosci. Model Dev., 5, 741-760, https://doi.org/10.5194/gmd-5-741-2012, 2012.

Sindelarova, K., Granier, C., Bouarar, I., Guenther, A., Tilmes, S., Stavrakou, T., Müller, J.-F., Kuhn, U., Stefani, P., and Knorr, W.: Global data set of biogenic VOC emissions calculated by the MEGAN model over the last 30 years, Atmos. Chem. Phys., 14, 9317-9341, https://doi.org/10.5194/acp-14-9317-2014, 2014.

Sitch, S., Cox, P. M., Collins, W. J., and Huntingford, C.: Indirect radiative forcing of climate change through ozone effects on the land-carbon sink, Nature, 448, 791-794, https://doi.org/10.1038/nature06059, 2007.

Smith, R. N. B.: A scheme for predicting layer clouds and their water content in a general circulation model, Q. J. Roy. Meteor. 
Soc., 116, 435-460, https://doi.org/10.1002/qj.49711649210, 1990.

Stevenson, D. S., Young, P. J., Naik, V., Lamarque, J.-F., Shindell, D. T., Voulgarakis, A., Skeie, R. B., Dalsoren, S. B., Myhre, G., Berntsen, T. K., Folberth, G. A., Rumbold, S. T., Collins, W. J., MacKenzie, I. A., Doherty, R. M., Zeng, G., van Noije, T. P. C., Strunk, A., Bergmann, D., Cameron-Smith, P., Plummer, D. A., Strode, S. A., Horowitz, L., Lee, Y. H., Szopa, S., Sudo, K., Nagashima, T., Josse, B., Cionni, I., Righi, M., Eyring, V., Conley, A., Bowman, K. W., Wild, O., and Archibald, A.: Tropospheric ozone changes, radiative forcing and attribution to emissions in the Atmospheric Chemistry and Climate Model Intercomparison Project (ACCMIP), Atmos. Chem. Phys., 13, 3063-3085, https://doi.org/10.5194/acp-13-3063-2013, 2013.

Telford, P. J., Abraham, N. L., Archibald, A. T., Braesicke, P., Dalvi, M., Morgenstern, O., O'Connor, F. M., Richards, N. A. D., and Pyle, J. A.: Implementation of the Fast-JX Photolysis scheme (v6.4) into the UKCA component of the MetUM chemistry-climate model (v7.3), Geosci. Model Dev., 6, 161177, https://doi.org/10.5194/gmd-6-161-2013, 2013.

Trail, M., Tsimpidi, A., Liu, P., Tsigaridis, K., Rudokas, J., Miller, P., Nenes, A., Hu, Y., and Russell, A.: Sensitivity of air quality to potential future climate change and emissions in the United States and major cities, Atmos. Environ., 94, 552-563, https://doi.org/10.1016/j.atmosenv.2014.05.079, 2014.

von Schneidemesser, M. and Monks, P. S.: Air quality and climate - synergies and trade-offs, Environ. Sci.: Process Impacts, 15, 1315-1325, https://doi.org/10.1039/C3EM00178D, 2013.

Walters, D. N., Best, M. J., Bushell, A. C., Copsey, D., Edwards, J. M., Falloon, P. D., Harris, C. M., Lock, A. P., Manners, J. C., Morcrette, C. J., Roberts, M. J., Stratton, R. A., Webster, S., Wilkinson, J. M., Willett, M. R., Boutle, I. A., Earnshaw, P. D., Hill, P. G., MacLachlan, C., Martin, G. M., Moufouma-Okia, W., Palmer, M. D., Petch, J. C., Rooney, G. G., Scaife, A. A., and Williams, K. D.: The Met Office Unified Model Global Atmosphere 3.0/3.1 and JULES Global Land 3.0/3.1 configurations, Geosci. Model Dev., 4, 919-941, https://doi.org/10.5194/gmd-4919-2011, 2011.

Wanninkhof, R.: Relationship between wind speed and gas exchange over the ocean, J. Geophys. Res.-Oceans, 97, 7373-7382, https://doi.org/10.1029/92JC00188, 1992.

WHO: Health risks of air pollution in Europe HRAPIE project. Recommendations for concentration-response functions for cost-benefit analysis of particulate matter, ozone and nitrogen dioxide, World Health Organisation, available at: http://www.euro.who.int/en/health-topics/environment-andhealth/air-quality/publications/health-risks-of-air-pollution-ineurope-hrapie-project (last access: 23 October 2017), 2013a.
WHO: Review of evidence on health aspects of air pollution - REVIHAAP Project: Technical Report, World Health Organisation, available at: http://www.euro.who.int/en/health-topics/environment-andhealth/air-quality/publications/2013/review-of-evidence-onhealth-aspects-of-air-pollution-revihaap-project-final-technicalreport (last access: 23 October 2017), 2013b.

Wild, O., Zhu, X., and Prather, M.: Fast-J: Accurate Simulation of In- and Below-Cloud Photolysis in Tropospheric Chemical Models, J. Atmos. Chem., 37, 245-282, https://doi.org/10.1023/A:1006415919030, 2000.

Wilson, D. R. and Ballard, S. P.: A microphysically based precipitation scheme for the UK meteorological office unified model, Q. J. Roy. Meteor. Soc., 125, 1607-1636, https://doi.org/10.1002/qj.49712555707, 1999.

Wong, D. C., Pleim, J., Mathur, R., Binkowski, F., Otte, T., Gilliam, R., Pouliot, G., Xiu, A., Young, J. O., and Kang, D.: WRFCMAQ two-way coupled system with aerosol feedback: software development and preliminary results, Geosci. Model Dev., 5, 299-312, https://doi.org/10.5194/gmd-5-299-2012, 2012.

Woodward, S.: Modeling the atmospheric life cycle and radiative impact of mineral dust in the Hadley Centre climate model, J. Geophys. Res.-Atmos., 106, 18155-18166, https://doi.org/10.1029/2000JD900795, 2001.

Yienger, J. and Levy II, H.: Global inventory of soil-biogenic $\mathrm{NO}_{x}$ emissions, J. Geophys. Res., 100, 11447-11464, 1995.

Zhang, Y., Karamchandani, P., Glotfelty, T., Streets, D. G., Grell, G., Nenes, A., Yu, F., and Bennartz, R.: Development and initial application of the global-through-urban weather research and forecasting model with chemistry (GU-WRF/Chem), J. Geophys. Res.-Atmos., 117, D20206, https://doi.org/10.1029/2012JD017966, 2012. 